\title{
Central versus wellhead power plants in geothermal grid electricity generation
}

\author{
Moses Jeremiah Barasa Kabeyi ${ }^{*}$ (D) and Oludolapo A. Olanrewaju(B)
}

\begin{abstract}
The long gestation period, high upfront costs and the risks in the development of central geothermal power plants are the main reasons for the slow rate of geothermal electricity growth and its contribution to the global electricity mix. The overall objective of this study was to make a comparison between central geothermal power plants and wellhead power plants in the delivery of geothermal electricity projects. The study showed that wellhead power plants are generally less efficient compared to central power plants because of higher specific steam consumption, but are financially attractive because of the quicker return on investment, early electricity generation and the lower financial risks. The study showed that permanent wellhead power plants are a better option for geothermal wells with too low or too high steam pressure compared to others in the steam field. Temporary use of wellhead power plants as opposed to their permanent use is preferred when only limited time is available between the commissioning of a wellhead plant and the commissioning of a central power plant in the same steam field. Technical, operational and environmental challenges, including higher specific steam consumption and lower efficiency than central power plants as well as absence of geothermal fluid reinjection system make wellhead plants less economical and less sustainable in resource use. It can thus be concluded that wellhead power plants can reduce the long wait to generate geothermal electricity and make an early return on investment for investors. Both central and wellhead power plants have relatively higher capacity factor than many other power plants and so can be used to supply base load electricity for the grid or off-grid power supply. This study is a review of the central and wellhead power plants and additionally provides policy guidelines in the execution of geothermal electricity projects either as central or wellhead power plants for grid electricity generation.
\end{abstract}

Keywords: Central geothermal power plant, Challenges of geothermal electricity, Geothermal project cycle, Electricity generation, Geothermal electricity, Sustainable electricity, Wellhead power plants

\section{Introduction}

Geothermal energy is extractable heat energy from the earth's crust which can be mined by drilling wells for hot water and steam extraction [1]. The huge potential of geothermal energy is significantly restricted by social, technical and economic factors $[1,2]$. One of the reasons why geothermal energy has made only a limited contribution to the global electricity mix is that it takes a long

*Correspondence: 22064693@dut4life.ac.za Industrial Engineering Department, Durban University of Technology, Durban, South Africa period of time from the resource discovery time to the time the power plant is commissioned [3]. The result of this delay places financial pressure on the project, often making it financially unattractive not just to financiers, but to investors as well because they usually have alternative projects to consider [4]. Geothermal energy for electricity generation has several benefits over other sources of energy [5]. These benefits include low cost energy, low emissions, a high power plant capacity factor and low land requirements, among others [4]. With significant potential, geothermal energy has a very important role in the energy transition [6]. original author(s) and the source, provide a link to the Creative Commons licence, and indicate if changes were made. The images or other third party material in this article are included in the article's Creative Commons licence, unless indicated otherwise in a credit line to the material. If material is not included in the article's Creative Commons licence and your intended use is not permitted by statutory regulation or exceeds the permitted use, you will need to obtain permission directly from the copyright holder. To view a copy of this licence, visit http://creativecommons.org/licenses/by/4.0/. The Creative Commons Public Domain Dedication waiver (http://creativeco mmons.org/publicdomain/zero/1.0/) applies to the data made available in this article, unless otherwise stated in a credit line to the data. 
There has been considerable interest in geothermal electricity due to increasing concerns over greenhouse gas emissions and global warming [5]. Global electricity generation processes cumulatively account for over $40 \%$ of combined global energy demand and remain a good indicator of a country's economic progress and performance [7]. Where greenhouse gas emissions are concerned, electricity generation alone accounted for $42 \%$ of global $\mathrm{CO}_{2}$ production in 2013 followed by transport, which contributed $23 \%$ to global emissions [8]. The rapid growth in energy demand globally has led to more consumption of fossil fuels, which has led to ongoing pollution of the ecosystem. These environmental concerns have led to an increased demand for renewable energy, of which geothermal is a very important source, to meet the ever-growing demand for energy [9]. On a positive note, global energy and electricity-related carbon emissions $\left(\mathrm{CO}_{2}\right)$ flattened to about $33 \mathrm{Gt}$ (Giga tons) in the year 2019, which was an indication of a decline in emissions from 33.1 Gt (Giga tons) realized in 2018. This could be attributed to an increase in renewable energy generation from sources like solar PV and wind, switching from coal to natural gas, and nuclear energy capacity growth [10]. This improvement did not, however, significantly feature geothermal energy, yet it could play a leading role in energy transition from fossil fuel-dominated electricity mix.

The objective of this study was to analyze the capacity and application of both wellhead power plants and central power plants in electricity generation under different scenarios and identify the best system for specific circumstances. These circumstances include steam field characteristics, economic/financial considerations, and technical viability for faster resource development and exploitation and maximum benefits from the geothermal resource. This paper serves as a review and also suggests policy guidelines for geothermal project developers, financiers and policy-makers aimed at accelerating geothermal electricity development using both wellhead power plants and central power plants.

\section{Background to the study}

The energy potential of geothermal resources is significant in relation to the energy needs of the entire world and as such could play a leading role in global sustainable energy transition [11]. Geothermal energy is created by the natural internal heat of the earth found within rocks and fluids.

\section{Historical perspective}

The word geothermal is derived from two Greek words 'geo' and 'thermos' where geo means earth and thermos means heat [12]. Thus, the word geothermal means heat from the earth, or the earth's heat. Geothermal resources are renewable and can supply base load electricity and other direct uses sustainably while mitigating against greenhouse gas emissions from conventional sources, which are mainly fossil fuels [12-14].

The first industrial use of geothermal energy was in the production of boric acid in the borax industry at Larderello in the Tuscany region of Italy. Based on the insights developed in this industry, Francesco De Larderei built the first geothermal energy plant in 1827. It was, however, not until 1904 that Pietro Ginori Conti powered the first five light bulbs from geothermal energy. In 1913 the first real geothermal power plant was built to start a new era of geothermal electricity production $[15,16]$.

The global geothermal capacity is significant with $99 \%$ of the earth being hotter than $1000{ }^{\circ} \mathrm{C}$. Additionally, $99 \%$ of the remaining $1 \%$ which is below $1000{ }^{\circ} \mathrm{C}$ has a temperature higher than $100{ }^{\circ} \mathrm{C}$ [12]. The energy stored within the earth's crust alone is substantial and corresponds to about 10,500 times the world's total fossil fuel reserves [17, 18]. Therefore, geothermal energy stored in the earth's crust alone has the capacity to supply the entire energy needs of the world at the current rate of consumption [19]. As a reliable energy source, geothermal power plants have a system reliability of more than $95 \%$ with a load factor greater than $95 \%$ for most power plants [5].

\section{Geothermal electricity capacities and technology for wellhead and central plants}

Geothermal energy has huge potential for three main applications, i.e., geothermal heat pumps, direct heat applications and geothermal electricity [20,21]. Whereas the potential is huge, geothermal electricity project delivery for electricity generation continues to record slow growth rates and makes a limited contribution to electricity generation globally compared to other renewable sources of energy like wind and solar. According to [22], about 1.8 GWe capacity growth was realized over the period 2005 to 2010, which translates to just $20 \%$ growth in 5 years, representing an average of about $350 \mathrm{MW}$ more capacity per year or just $4 \%$ growth in geothermal electricity generation capacity globally. Between 2000 and 2005 a slower increment of about $200 \mathrm{MW} /$ year was realized globally [5, 22]. Ref. [5] observed that whereas the global undeveloped geothermal electricity capacity was over $100 \mathrm{GW}$, its growth was low and on average it had been between 1 and $5 \%$ on a year-to-year basis for the last two decades [5] with globally shared total electricity generation being less than $1 \%$.

On generation technology, [23] stated that most geothermal electricity came from central power plants whose capacity ranged from 50 to 100 MWe. However, 
due to rapid expansion and high demand for geothermal electricity, the demand for wellhead power plants has significantly increased. According to [24], wellhead plants assume the shape of a conventional geothermal power plant but on a smaller scale as they often use steam from a single well. Once the central power plant was constructed, the wellhead plants are relocated other locations in need. According to [25], wellhead units may be connected to geothermal wells with a capacity of up to $15 \mathrm{MW}$ and require shorter steam lines. Ref. [23] noted that a wellhead generator was a road-transportable energy conversion system with capacity of 1-10 MW but with a minimum practical size of 3-5 MWe based on economic considerations. Therefore, wellhead power plants generally have a capacity of $0.1 \mathrm{MW}$ to $15 \mathrm{MWe}$. In his work [2] observed that with financial incentives like tax rebates, wellhead plants have a return on investment of about 3 to 4 years without taking the tax incentives offered on wellhead plants into account [26]. These figures might vary from country to country or according to the technology used, so each project should be subjected to a detailed financial/economic feasibility analysis.

\section{Growth in generation capacity between 1995 and 2019}

The global installed capacity of geothermal energy has grown over the last decade to reach an effective capacity of 13.93 GWe [27] and an installed capacity of 15.40 gigawatts in 2019 [28, 29]. Geothermal technologies were among the notable growing renewable energy technologies and options occurring across the world. These technologies were seen as environmentally friendly mainly due to lower emissions [10,30,31]. Table 1 shows geothermal generation capacity between 2005 and 2019 globally.

Table 1 shows that between 2005 and 2019 the total growth in geothermal generation capacity was 6714 MWe, representing an average annual increment in geothermal generating capacity of $447.60 \mathrm{MW}$ and representing an average annual growth rate of $5.15 \%$ on a year-to-year basis. It should be noted that installed generating capacity was less than actual, or effective generating capacity due to various factors related to design, operation and maintenance of the power plants. These growth rates were slow compared to other renewable energy sources like wind and solar [28].

\section{Renewable energy in electricity generation}

The first quarter of 2020 realized about 1.5\% higher generation from renewable energy sources compared to the same period for 2019. This growth in generation was due to $100 \mathrm{GW}$ from solar and $60 \mathrm{GW}$ from wind power coming from new power projects. The global share of electricity from renewable energy sources in the first quarter of 2020 reached 28\%, up from $26 \%$ in the first quarter of 2019. Over the same period, the contribution from various renewable sources, i.e., wind and solar, rose from 8 to $9 \%$. Coal and gas still led with a contribution of about $60 \%$ to global electricity [30,31]. This showed the growing contribution of renewable energy sources to global electricity generation.

Table 1 Global installed capacity of geothermal [5, 32]

\begin{tabular}{lllll}
\hline & Year & Global capacity (MWe) & Capacity growth (MWe) & $\begin{array}{c}\text { Percentage } \\
\text { growth (\%) }\end{array}$ \\
\hline 1 & Reference year & & & 232 \\
2 & 2005 & 8686 & 221 & 2.67 \\
3 & 2006 & 8918 & 320 & 3.50 \\
4 & 2007 & 9139 & 440 & 4.65 \\
5 & 2008 & 9459 & 222 & 2.24 \\
6 & 2009 & 9899 & -110 & -1.09 \\
7 & 2010 & 10,121 & 460 & 4.59 \\
8 & 2011 & 10,011 & 269 & 2.57 \\
9 & 2012 & 10,471 & 481 & 4.48 \\
10 & 2013 & 10,740 & 625 & 5.57 \\
11 & 2014 & 11,221 & 860 & 7.26 \\
12 & 2015 & 11,846 & 574 & 4.52 \\
13 & 2016 & 12,706 & 1320 & 5.94 \\
14 & 2017 & 13,280 & 800 & 5.48 \\
15 & 2018 & 14,600 & $447.60 /$ year & $5.15 \%$ \\
\hline Total/Ave & 2019 & 15,400 & 6714.0 MWe &
\end{tabular}


From the year 1990, renewable energy sources recorded an average annual growth rate of $2.0 \%$, compared to the world's total energy supply growth average of $1.8 \%$. Solar PV led with an annual growth rate of $36.5 \%$, followed by wind at $23.0 \%$. Biogases came in at third highest with an average growth rate of $11.5 \%$, followed by solar thermal at $10.9 \%$ and liquid biofuels at 9.7\% [31]. Geothermal lagged behind with average growth of 5.15\% between 2005 and 2019 as shown in Table 1.

\section{Geothermal electricity generation technology for central power plants}

There are three conventional technologies and a combination of one or more of them that could be used to exploit geothermal resources for electricity generation [5, 32, 33]. These technologies are discussed below.

\section{Dry steam plants}

These power plants use dry steam from production wells piped directly to the steam turbine. There are very few geothermal fields with dry steam, with Larderello in Italy being one of them together with the geysers of the USA [5]. Dry steam turbines used in dry steam plants require geothermal fluids with temperatures of at least $150{ }^{\circ} \mathrm{C}$. These turbines can be backpressure or condensing-type turbines. For backpressure steam turbines, steam is passed through the turbine and vented into the atmosphere, leading to twice the amount of steam consumption per produced kilowatt-hours (kWhrs), compared to a similar condensing cycle turbine working with the same amount of steam. Backpressure turbines are commonly used as pilot, or standby plants in the case of small supplies from remote isolated wells as well as for generating electricity in the early stages of field development in wellhead power plants. They are ideal where geothermal fluid has a high non-condensable gas content in excess of $12 \%$ in weight since the exhaust is vented into the atmosphere $[13,34]$. Both central and wellhead power plants can be used if they are developed to use dry steam resources [2].

\section{Flash steam plants (single, double and triple)}

Flash steam plants are commonly used for water-dominated reservoirs with temperatures above $150{ }^{\circ} \mathrm{C}$. The hot pressurized water flows up the well until its pressure decreases to the stage where it vaporizes, leading to a two-phase water-steam mixture. Steam separated from the water is piped to the turbine while separated leftover brine, together with the condensed steam may be piped back into the source reservoir through reinjection wells, or disposed of through other means [34]. The flash steam plants work effectively for both central and wellhead plants flash steam plants are the most commonly used technology in geothermal electricity generation [5].

\section{Binary power plants}

The conversion process in binary power plants involves vaporizing a working fluid with a low boiling point, which could be a hydrocarbon like isobutene. These plants can be organic Rankine cycle plants or Kalina plants depending on the working fluid used. Binary plants can generate electricity from low-temperature geothermal sources typically within the $100-120^{\circ} \mathrm{C}$ range and even down to a low $70-75{ }^{\circ} \mathrm{C}$, depending upon the availability of geothermal fluid [5, 34]. Binary technology can be used in both central and wellhead power plants. With wellhead plants the development process becomes more expensive and has a longer gestation period. Although the resultant plant will yield more power and have less environmental impact, binary technology may not be ideal for the quick development of temporary wellhead plants, but may be more suitable for central power plants and permanent wellhead power plants [2].

\section{Combination of the conventional technologies}

The heat content of a geothermal fluid typically determines the technology used on a long-term basis. Dry steam plants generally use steam of $150{ }^{\circ} \mathrm{C}$ or higher and the steam entering the turbine needs to be at least $99.9 \%$ dry to avoid scaling and/or erosion of the turbine or piping components [32]. Flash steam plants typically require resource temperatures in the range of $177^{\circ} \mathrm{C}$ to $260{ }^{\circ} \mathrm{C}$, whereas binary plants, which include Kalina plants, are designed to utilize geothermal fluids in the range of $85^{\circ} \mathrm{C}$ to $170{ }^{\circ} \mathrm{C}$ with the working fluid being an organic gas like isobutane or a $\mathrm{NH}_{3} / \mathrm{H}_{2} \mathrm{O}$ mixture. Single flash plants have limited ability to provide flexible power, while binary systems are flexible and can be used alongside other technologies that use high enthalpy steam whose output can be utilized in binary systems [32, 35-37].

In combination power plants, the geothermal fluid is first used for high-enthalpy applications such as dry steam power plants or flash steam technology from where the fluid is taken to a lower enthalpy generation like organic Rankine/Kalina after which the geothermal fluid may be re-injected through a reinjection well [5, 38]. The complex nature of these plants makes it difficult to adopt the technology for temporary wellheads, but it may be considered for permanent wellhead power plants or cases where the development of a central power plant would take a much longer period of time $[2,5]$. 


\section{Geothermal power project cycle management}

Geothermal electricity development consists of a succession of phases, which can be broadly categorized as resource exploration, confirmation of geothermal resources, site, or field development, and power production [39]. These phases can be generally divided into two main parts, i.e., exploration and exploitation. Geothermal resource exploration comes with high uncertainty and risks. The objective of the exploration phase is reservoir identification and location, and includes the study of possible resource use. This comes with significant financial risks that must be managed, probably by the use of lowcost investments. On the other hand, the exploitation stage has minor risks but demands massive investment [40]. Overall, a project has important dimensions which must be managed and controlled, namely, budget, time and scope [41, 42].

The geothermal project development cycle consists of five phases, namely resource exploration, resource assessment, power plant construction, plant operations and decommissioning. Each of these phases has several steps, or stages ranging from desktop studies, appraisal drilling, well testing, production drilling, plant operations and finally, decommissioning. In some cases, geothermal development has a different number of stages but the objective is similar based on prevailing policy and legislative framework $[43,44]$. A geothermal power project comprised the following stages: i. Preliminary reconnaissance, which involves the study of geology and geochemistry, a geophysics survey and a review of the information on the prospective area.

ii. A detailed surface exploration, which may include a temperature gradient drilling survey.

iii. Exploration drilling and well testing to establish well sustainability/potential and capacity.

iv. Feasibility studies, which include project review and planning.

v. Geothermal field development, which includes production drilling, power plant design and environmental impact assessment.

vi. Geothermal power plant construction and commissioning.

vii. Operation and management, including reservoir management and further development.

viii. Power plant shutdown and abandonment/decommissioning after the generation contract or termination of contract.

Figure 1 demonstrates the geothermal project cycle with the stages at which it is possible to generate electricity and hence get early power and return on investment.

Figure 1 shows that early generation and cash inflow can be realized as early as the end of the exploration drilling when productive wells are encountered. Other stages are the field development and the power construction phase. Some wells can be allowed to run on a permanent basis based on an analysis of the entire steam field.

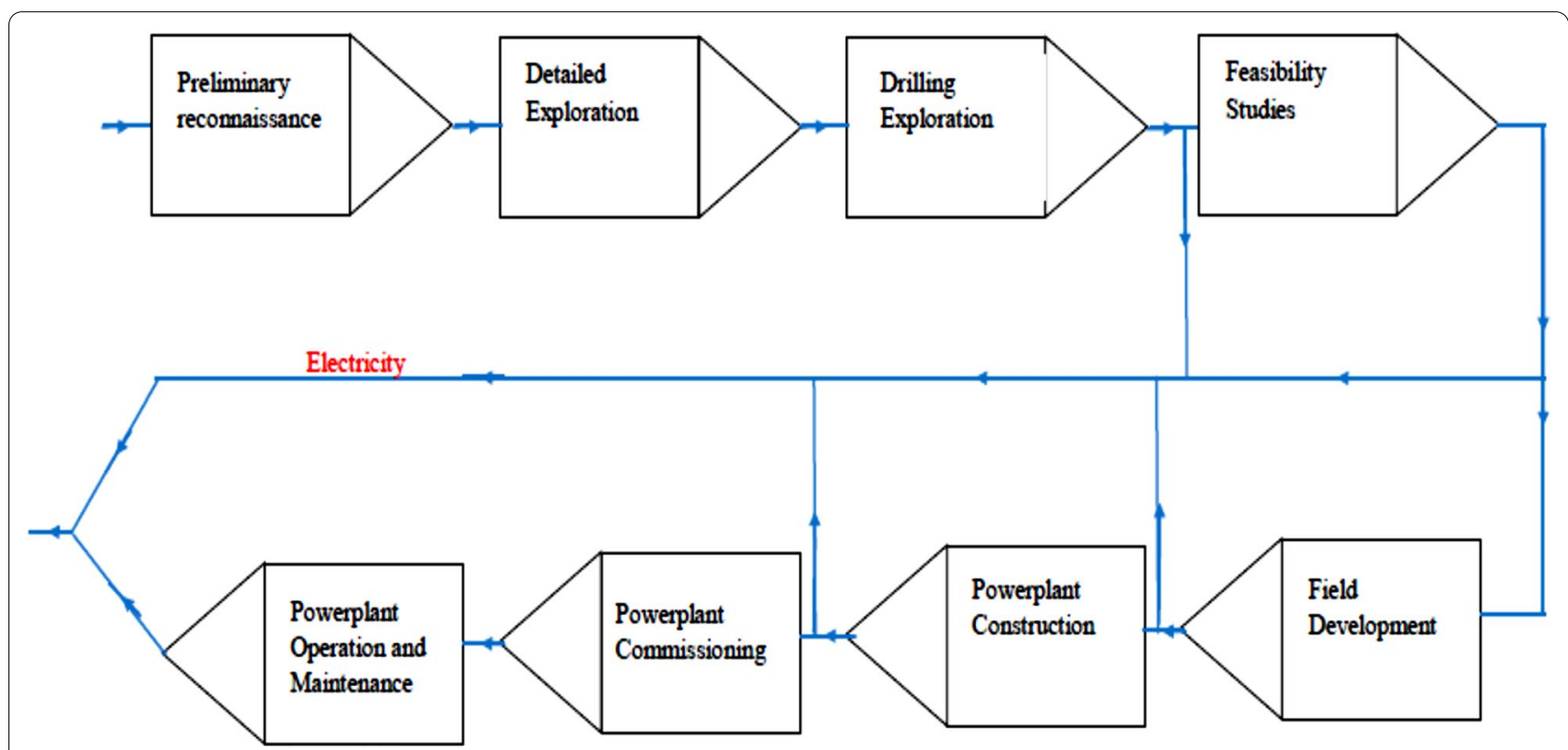

Fig. 1 Geothermal electricity project development cycle with stages of possible electricity generation [2] 


\section{Problem statement}

It takes 7 to 10 years to complete a geothermal power plant project, which has contributed to the low average annual generation capacity growth $[2,5]$. However, the normal gestation period for a geothermal power plant project from project initiation to power station commissioning takes about 8 years but with ready project financing it could be reduced to 5 years $[2,45,46]$. Additionally, geothermal energy development and exploitation is a highly risky business undertaking [14], hence the need to develop cheaper and more efficient technologies and approaches in project implementation. Geothermal development involves drilling several wells, one after another, which, according to [24], leaves successfully drilled production wells idle for many years while awaiting the drilling of more wells to supply sufficient steam for a central power plant. This is wasteful and represents lost generation from the idle wells.

Wellhead power plants could be used temporarily to generate electricity from wells that had been drilled and tested to supply electricity for field development and to the grid, hence generating early financial benefits and return on investment ahead of project completion. However, the operation of geothermal wellhead plants is associated with challenges such as noise pollution, emission of gases like hydrogen sulphide and carbon dioxide, which air pollution, while atmospheric venting of wellheads due to trips or lost load could lead to conflict with the surrounding community due to deposits which could spread to nearby settlements as witnessed in cases like the Eburru wellhead plant in Kenya $[47,48]$. There is a need to establish the potential of wellhead power plants as a feasible solution to challenges facing the development and exploitation of the significant but unexploited geothermal resources, which included long gestation periods and substantial development costs as well as the risks associated with project development [42, 49].

Other challenges associated with geothermal power according to $[5,14,50]$ included:

i. It is difficult to predict the potential of a given site or steam field, hence the increased development risks as resources have often been spent without success being guaranteed.

ii. The geological conditions, reservoir characteristics and the chemical as well as the physical properties of each geothermal well and steam field is unique, making standardization in geothermal resource development and exploitation difficult, which has created an optimization challenge.

iii. Most interesting geothermal sites are geologically unstable due to possible volcanic activity and earthquakes, and are hence risky. This adds an ele- ment of uncertainty to the overall project development which incurs additional costs to the project.

iv. Geothermal projects need huge capital expenditure for geothermal development, and risky investment in upfront activities makes it difficult to attract financing capital as there is no guarantee of success after the massive investment.

v. Most geothermal resources are located in remote areas with poor infrastructure and located far from loading centers and transmission grid facilities. This has led to higher development costs and investment in electricity transmission infrastructure, making the project more costly and time consuming to realize.

vi. Geothermal fluid releases condensable gases requiring control that influences the type of technology used: backpressure turbines emit these gases directly into the atmosphere while closed loop systems/binary systems retain the gases in the fluid and are re-injected into the steam field.

vii. Weak financial indicators such as substantial upfront costs, stringent bank loan conditions by financiers, extended payback periods, and difficulty in resource discovery discourages investors and project proponents whose upfront costs are typically high and are seen as risky.

viii. Clear enabling policy and a sound legal environment are necessary to promote investment in geothermal energy.

ix. There are technical barriers which include reliance on a wide range of professionals such as reservoir engineers, geologists, mechanical engineers, electrical engineers, drilling engineers, surveyors and other professionals with the necessary infrastructure and skills who are potentially in short supply in many countries.

$x$. Whereas geothermal energy is relatively environmentally friendly, resource development and exploitation is associated with noise, greenhouse gas emissions, surface disturbance, displacement of humans and corrosive brine and has an undesirable visual impact. Therefore, making geothermal development socially acceptable and adhering to environmental regulations present a challenge in many cases.

xi. Most globally accessible geothermal resources have low enthalpy resources which poses a challenge for electricity generation using cheaper conventional technologies.

xii. The reinjection of brine where reinjection wells are not incorporated has presented a challenge especially for small power plants. This can cause envi- 
ronmental pollution and unsustainable geothermal resource exploitation.

These challenges among others have contributed to low growth in geothermal generation capacity and low contribution to the global electricity mix. The many stages and phases and related challenges have effectively led to long project gestation periods $[5,50]$. Wellhead power plants have demonstrated the ability to reduce the long waiting time to realize electricity and revenue from geothermal electricity projects.

\section{The wellhead versus central powerplants}

Geothermal steam fields may cover huge tracts of land covering many square kilometers, making the distance between wells to be interconnected significantly long and therefore expensive to implement in central power plants. This often raises the question as to whether it would be prudent to install a power plant next to each wellhead or develop a large central power plant for all the wells to be interconnected. This decision should be based on several considerations such as the characteristics of the geothermal fluid of each well in the steam field, the land topography, financial and economic considerations, technical factors such as efficiency and reliability considerations, and existing policy and regulatory frameworks [4].

\section{Central power plant}

A central geothermal power plant, which is the conventional power plant, consists of several geothermal wells interconnected to contribute steam for the operation of a common turbine or several turbines. Therefore, they require extensive field development with several pipelines joining the production wells to the turbines in the power house $[4,5,38]$. Figure 2 illustrates the general configuration of a central power plant with several wellheads $(\mathrm{WH})$ interconnected by steam pipelines.

Figure 2 shows a central power plant served with steam from all the ten wellheads (WH) in a steam field through a network of steam pipes running across the steam field. This is different from a wellhead power plant where each production well has a power plant located next to it as shown in Fig. 3. It should be noted that these wells have unique characteristics yet they have to be interconnected to a central power plant $[5,38]$. Figure 3 shows the overall general construction of a central power plant.

Figure 3 illustrates Nesjavellir Power Station in Iceland with a capacity of about $120 \mathrm{MWe}$, and a flow rate of $1100 \mathrm{~L}$ of hot water at $82-85{ }^{\circ} \mathrm{C}$ per second at a heating capacity of $150 \mathrm{MWth}$, used for space heating. It shows the power station connected to several wells by long steam pipes. Therefore, central power plants can be designed to supply thermal and water for direct applications in addition to electricity generation.

\section{Wellhead power plants}

Wellhead technology involves using steam from geothermal wells that have been drilled and are productive but remain idle, awaiting the development of a conventional geothermal power plant to generate electricity. In some cases, wellheads are built on a permanent basis on isolated geothermal wells. This makes it possible for investors to get early electricity and cash inflow before the completion of a central power plant or continue with generation from a single or a few production wells in form of wellhead power plants [46]. In wellhead electricity

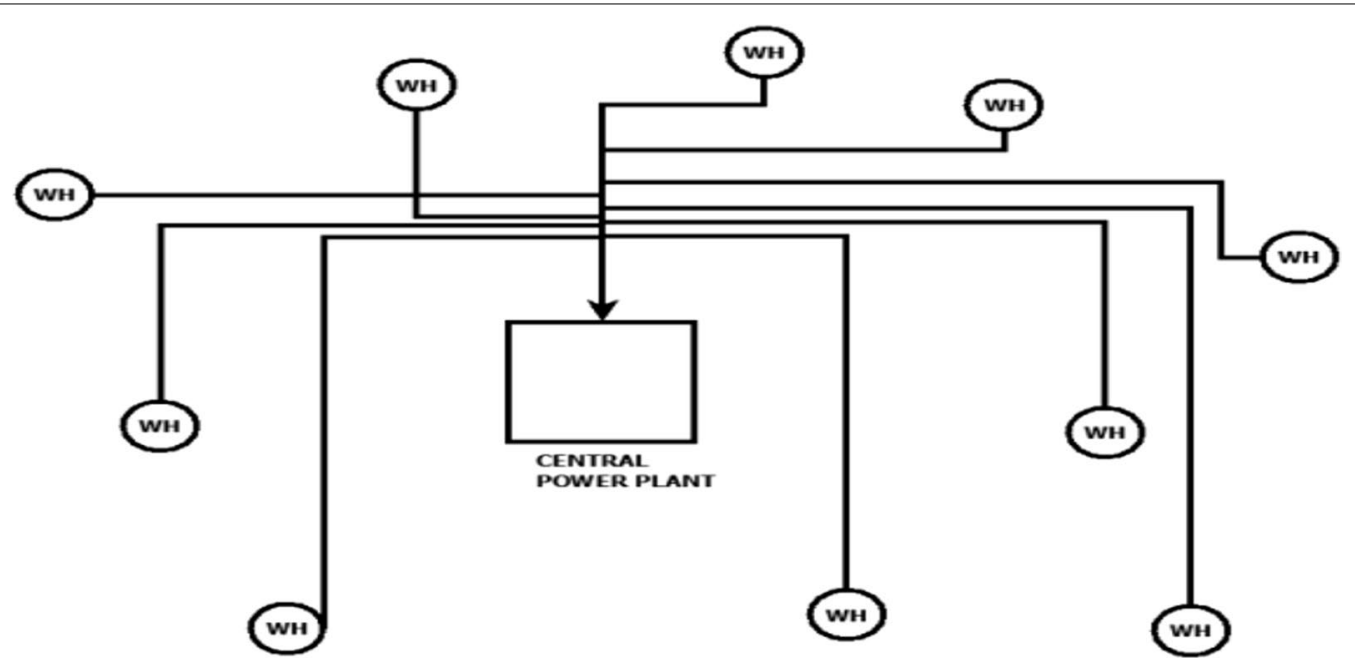

Fig. 2 Configuration of a central power plant [4] 


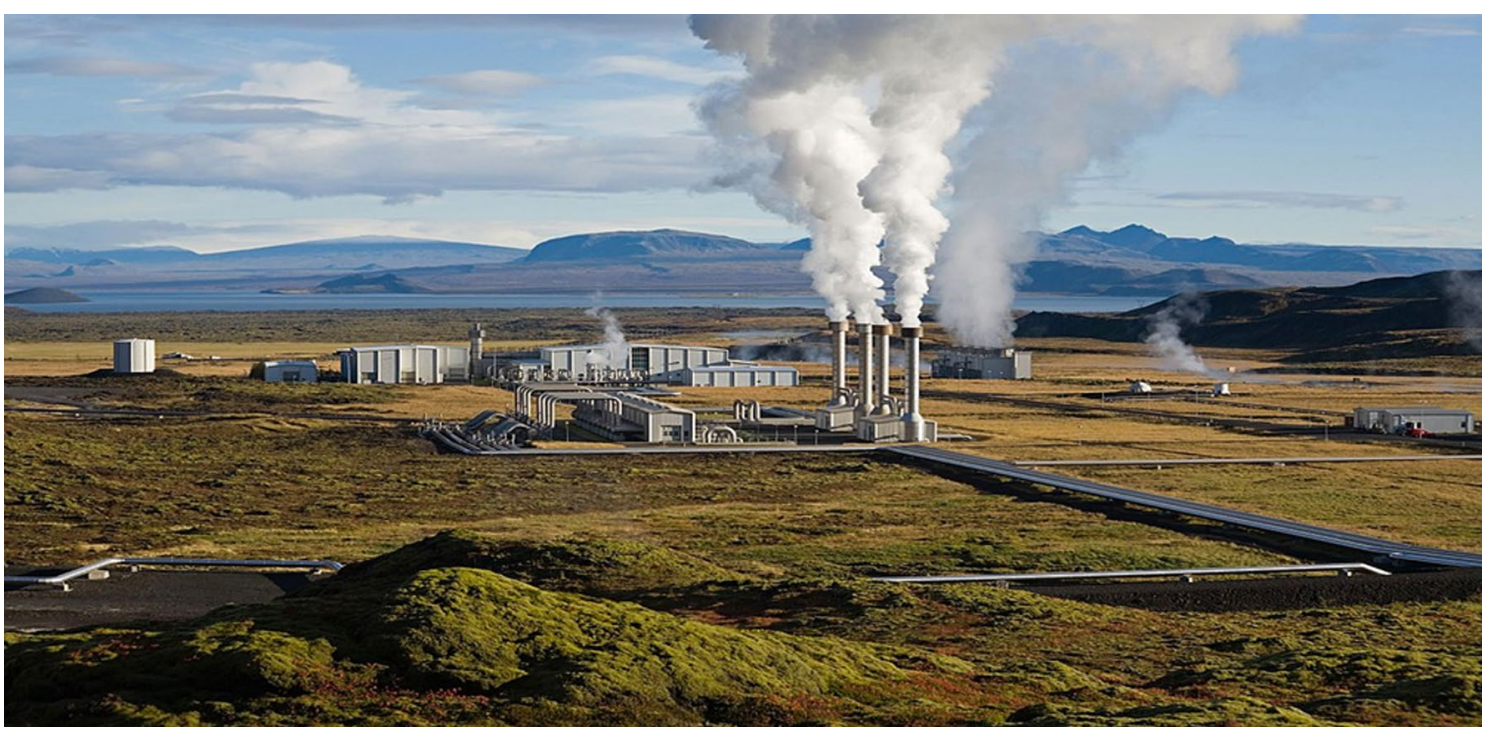

Fig. 3 Nesjavellir power station in Iceland, a central geothermal power plant [51, 52]

generation, steam from a geothermal well is converted to electricity in a wellhead power plant unit installed just above or close to the drilled geothermal well. The plant has no steam field development except for the brine and cooling tower blow-down disposal systems developed for the wellhead plant.

Figure 4 demonstrates the arrangement of wellhead power plants in a steam field.
Figure 4 shows a steam field with each well having a power plant next to it. Steam from the production well is piped to the wellhead generator unit which is just a few meters away. Figure 5 shows an operating 5 -MW wellhead power plant at Olkaria in Kenya installed on a well pad.

Figure 5 shows a wellhead plant at Olkaria with components constructed on a common foundation with just few
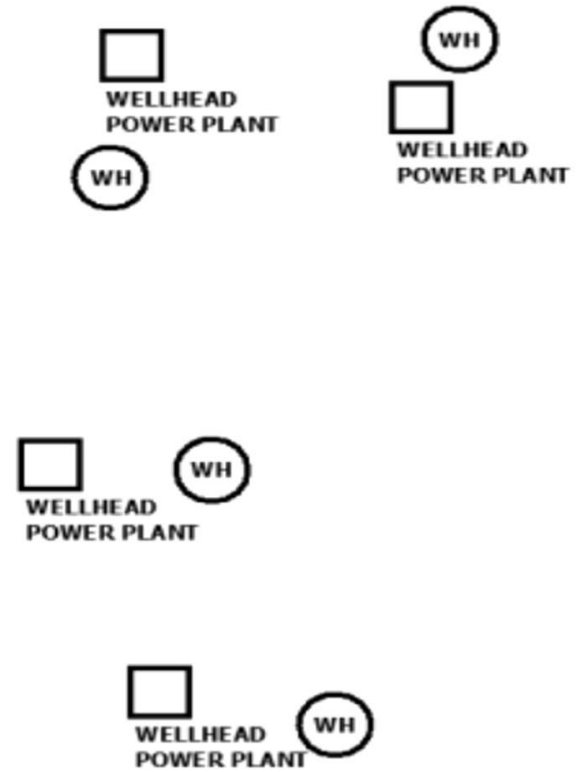

Fig. 4 Wellhead power plants [4]
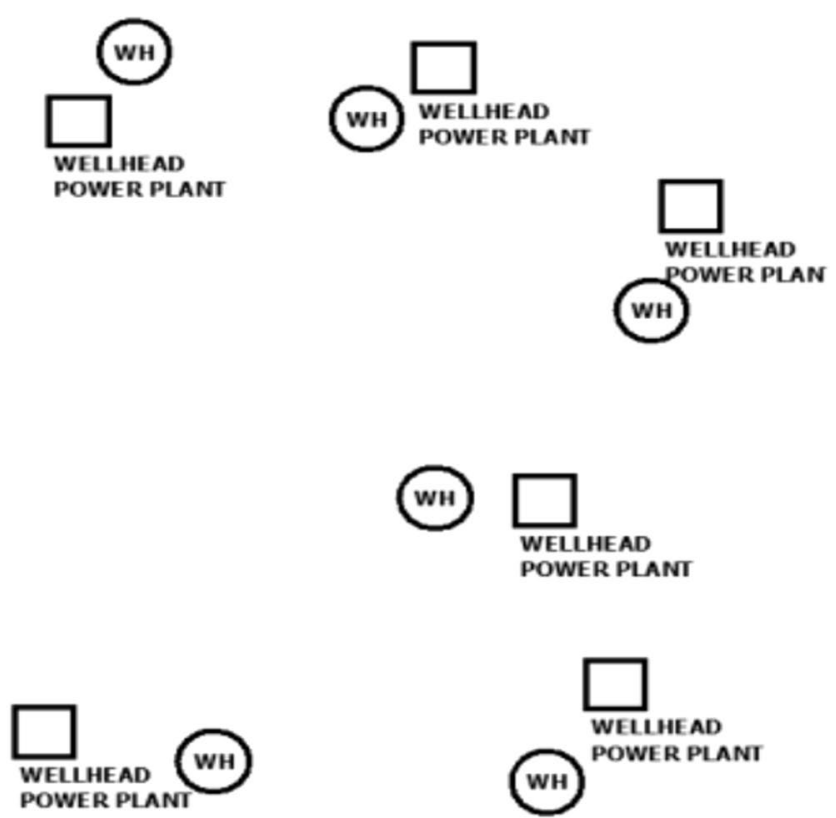


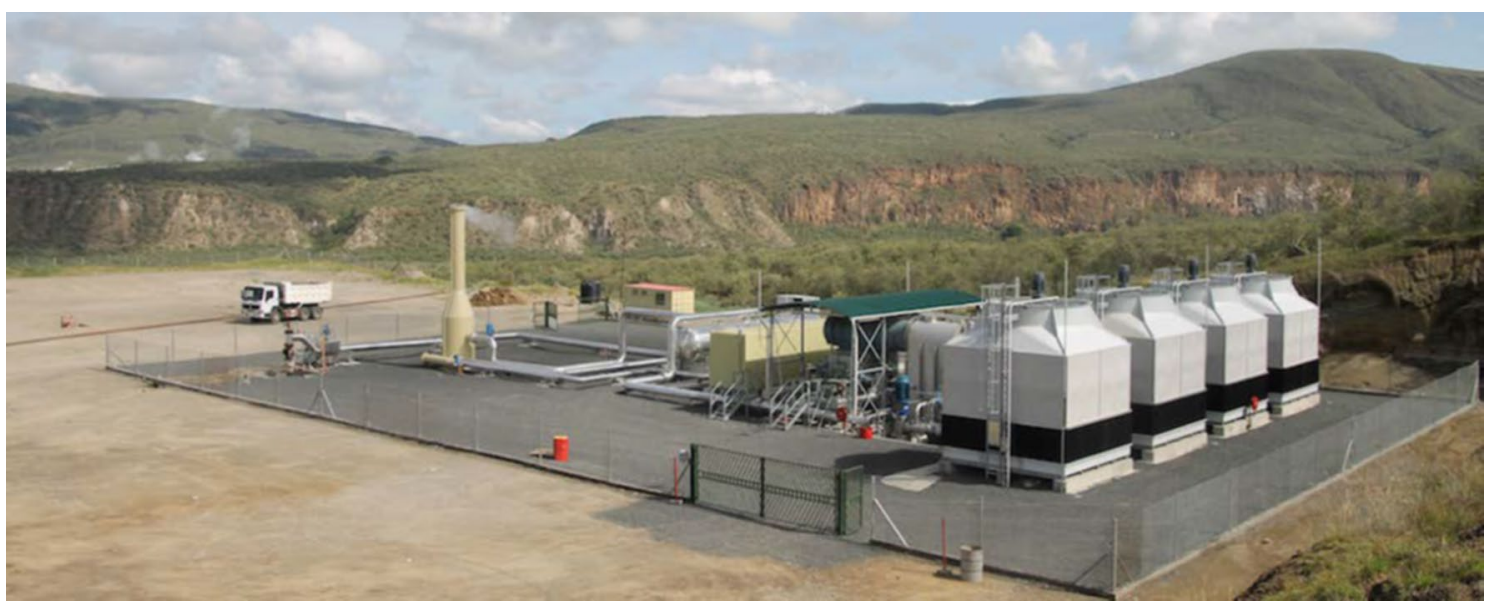

Fig. 5 A GEG 5-MW C50 wellhead plant at Olkaria in Kenya [53]

civil works and smaller parts compared to central power plants.

Wellhead power plants have fewer permanent civil works and could be containerized, or skid-mounted for easy and faster transfer from one well site to another [54]. This makes geothermal wellhead power plants simpler and cheaper to develop compared to central power plants. Ref. [55] defined a wellhead geothermal plant as 'a modular miniature electricity generating plant that is installed within the confines of a geothermal well pad'. The electricity generated from wellheads can be fed to the national or regional electricity grid depending on the applicable voltage and available electricity evacuation infrastructure. Wellhead power plants are relatively small in size and can be installed on the well pad of a geothermal well. They also vary in size, and generally generate between $100 \mathrm{kWe}$ and $15 \mathrm{MWe}[5,25,38,56]$. The installation is of short duration and generally takes between 3 and 6 months to assemble and commission.

Wellhead power plants can be used to optimize production by being customized to given well-specific conditions. They significantly overcome the shortcomings of traditional methods of exploiting geothermal resources such as long gestation periods and underutilization of some interconnected wells in central generation that have unique properties within a steam field $[2,5,21]$. According to [56], wellhead power plants could be developed as temporary installations and later relocated to new steam wells, or developed as permanent wellhead plants with no intention of relocation. This meant that decisions need to be made about either wellhead or central plants and then about temporary or permanent wellhead options by the planners, designers and investors for optimum resource development and use.

\section{Geothermal wellhead versus conventional/central power plant}

Generally, large power plants have a lower unit cost of power output and higher efficiency than small equipment and plants. However, geothermal wellhead plants have a similar capital cost per unit of power to large central power plants because of the simplified balance of plant systems and a more modularized arrangement, giving them the desired flexibility. Therefore, although wellhead plants are less efficient, they have considerable other benefits over and above the more efficient central power plants [56].

\section{Power plant efficiency and specific steam consumption}

Wellhead power plants, which generally consist of smaller equipment, have relatively lower efficiency and higher specific steam consumption than conventional geothermal power plants. This is a notable drawback of wellhead power plants compared to the central plants [56]. This is illustrated in Fig. 6, which shows the steam rate comparison between a large-scale central power plants and a small-scale wellhead plant of $5 \mathrm{MW}$ like the one made by the Green Energy Geothermal (GEG) company that manufactures geothermal wellhead power plants with standard sizes of 3.5 to $10 \mathrm{MW}$ per module [57].

From Fig. 6, it can be observed that as the steam inlet pressure reduces, the specific steam consumption increases for both central power plants and wellhead power plants, but the specific steam consumption (SSC) is relatively lower in central power plants compared to geothermal wellhead power plants. Therefore, central power plants have higher conversion efficiency than the wellhead power plants. 


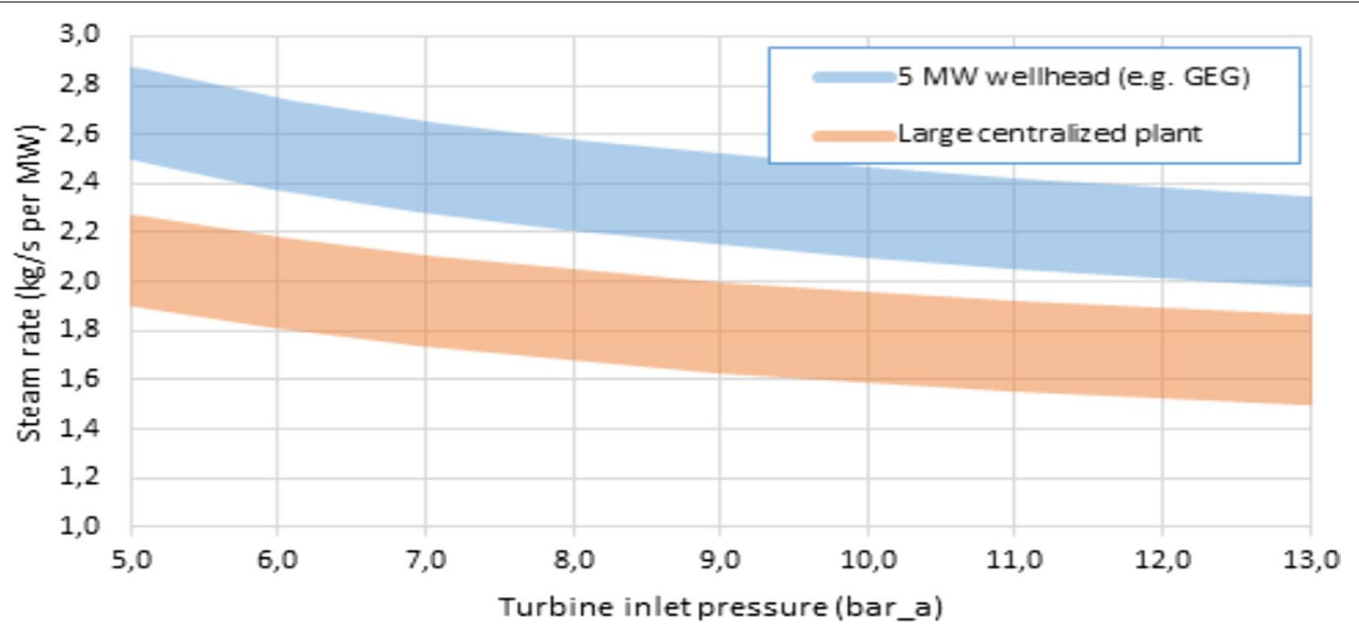

Fig. 6 Relationship between steam rate and turbine inlet pressure for wellhead and centralized geothermal plants $[5,57]$

\section{Separation pressure in wellhead and central power plants}

The steam separation pressure has a significant impact on the overall efficiency of the power plant. The selection of separation pressure requires an evaluation of the characteristic curves of the individual wells in order to select the optimal pressure $[2,56,58]$. Wells from the same steam field usually have different characteristics, hence the need to analyze the characteristics of each well separately [59]. Since the wells operate at a combined optimal single pressure system for central power plants, there is a need to optimize the pressure conditions which may render some wells ineffective at the selected pressure whenever their wellhead pressure is below the separation pressure. This leads to lost generation that can be as high as $5-20 \%$ of the installed geothermal capacity [56]. Figure 7 shows the well steam flow as a function of steam pressure for an individual well.
Figure 7 shows the steam pressure and flow characteristics of steam from a wellhead. In wellhead power plants, the steam has to be optimized separately for optimal performance in power generation from a given well in a steam field $[2,21]$. From Fig. 7 , it is noted that at no steam flow conditions, the pressure is about 37.5 bars while at zero wellhead pressure, the flow rate is about $44 \mathrm{~kg} / \mathrm{s}$. These two extremes are not desirable for optimum performance of a wellhead. In the case of a central power plant, all the wells are interconnected via a common steam separator or flash tank. Figure 8 illustrates steam at different pressures and the flow characteristics from different wells interconnected in a central power plant [4]. There is a need to select the separator pressure that will ensure optimum resource use and which may exclude some wells from the system.

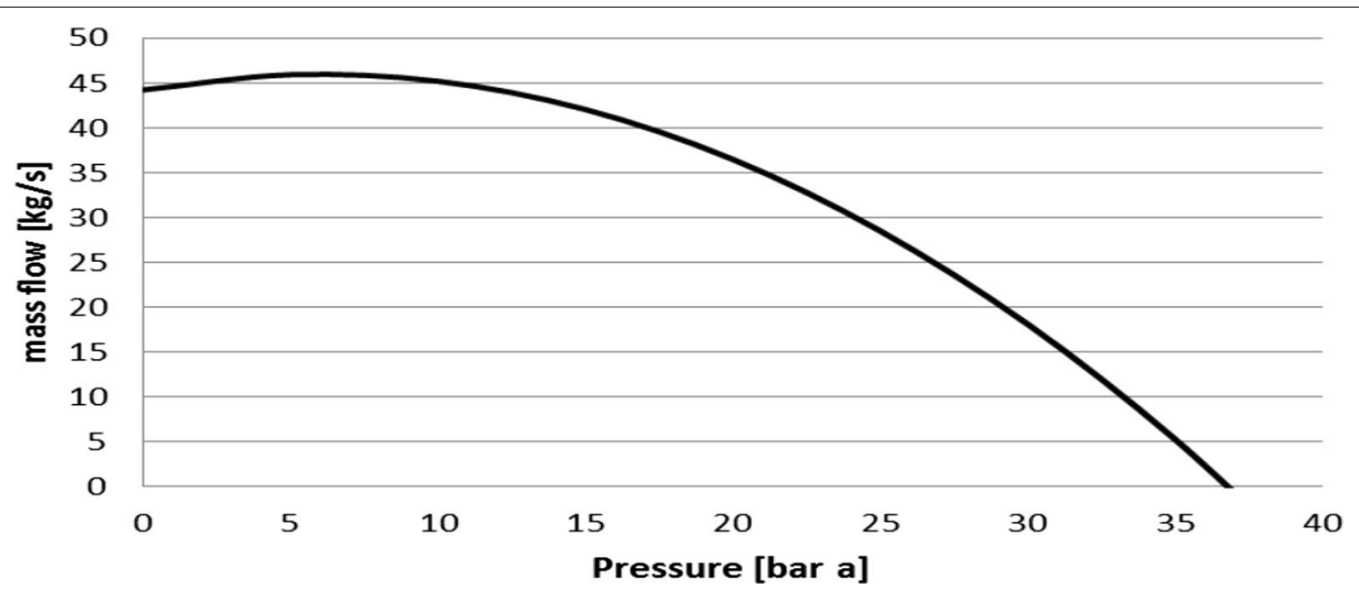

Fig. 7 Well flow rates as a function of steam pressure for an individual well [4] 


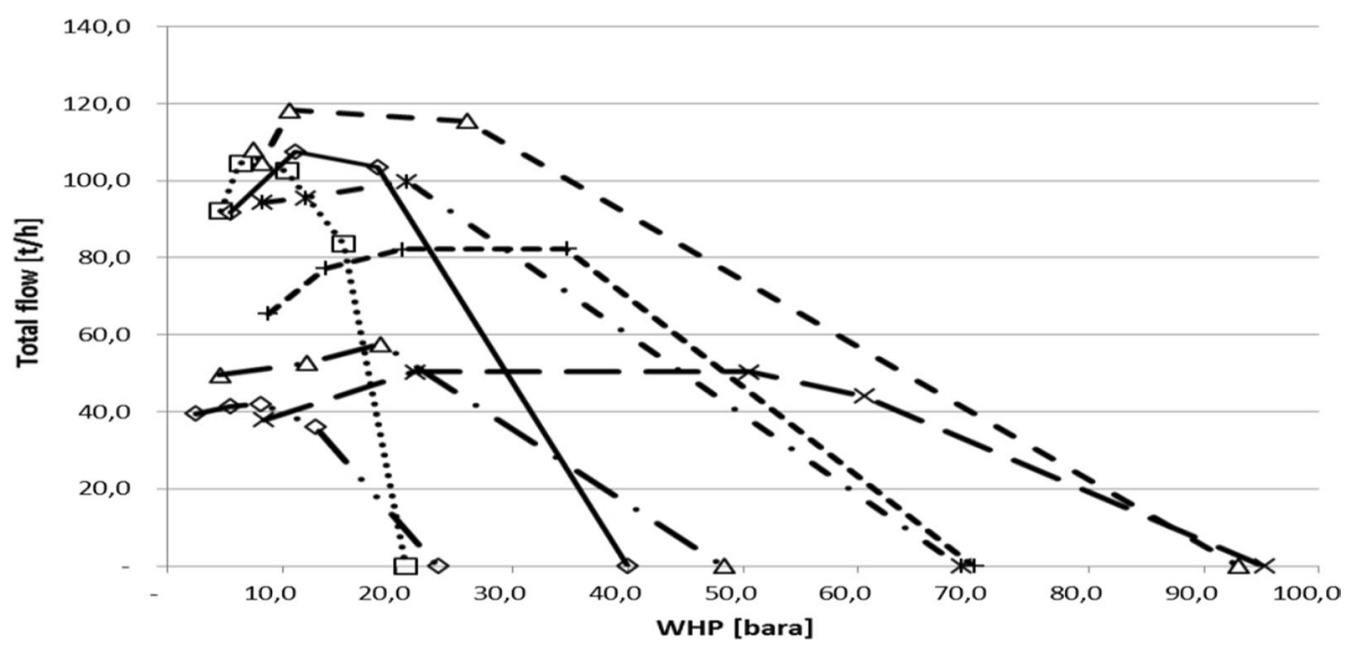

Fig. 8 Well flow rates as a function of steam pressure for interconnected wells [56]

Figure 8 shows well flow curves as a function of pressure and demonstrates that for wellhead power plants, individual wells can be operated independently at their own optimal pressure, eliminating wastage as a result of low closing pressure where central power plants are used. The result is higher total output from a given geothermal well and field. This counteracts the lower efficiency that results from using smaller equipment in wellhead power plants for electricity generation.

Therefore, developing a field with a wellhead instead of a large-scale plant is an option technically worth considering. Since each geothermal field and geothermal well has different characteristics, they each have to be analyzed separately before the wellhead power plant can be designed. If the geothermal field shows significant variation in individual well characteristics, wellhead power plants are a more feasible option than central power plants. It is also practical to have a mixed field development where both central power plants and wellhead plants are developed [56].

\section{Geothermal fluid collection systems}

Wellhead power plants are installed at the wellhead and therefore the steam gathering system is minimal compared to central geothermal power plants. The effect is the reduced cost of the piping system, pressure loss and visual pollution from pipe networks [5]. Spent geothermal liquid needs to be disposed of into the reservoir through reinjection wells, which facilitate sustainable and environmentally friendly utilization of geothermal fluid. However, in wellhead power plants the used fluid needs to be collected from each well and piped to the reinjection sites, which is a drawback as it increases costs [56].

\section{Control system for a wellhead versus central power plant}

The operation and control of wellhead power plants is such that each wellhead plant has its own instrumentation and control system. This implies that where the entire field is developed with wellhead plants, several similar control rooms are widely spread across the steam field, making it expensive and costly in terms of manpower and monitoring requirements compared to central power plants [56].

\section{Grid connection system}

Electricity from wellhead power plants may be connected to a high-voltage transmission system or a lowvoltage distribution network. In the latter case, the power evacuation is affected by consumer demand fluctuations and changing conditions, leading to instability and frequent tripping as in the case of Eburru wellhead power plant in Kenya [48]. The many wellhead power transmission lines interconnecting the wellhead generators and substations have a negative visual impact just like the steam gathering system of large/central power plants. It is, however, optional to put the power lines underground, but results in some additional cost. Such an option is currently not considered feasible for steam gathering piping [56].

\section{Non-condensable gas emissions}

Emission of non-condensable gases is the same for wellhead and central power plants as this is influenced by the chemistry of the geothermal fluid from a specific well. These gases, mainly carbon dioxide $\left(\mathrm{CO}_{2}\right)$ and hydrogen sulphide $\left(\mathrm{H}_{2} \mathrm{~S}\right)$ are spread over a larger area, hence there is better disbursement of these gases 
Table 2 Differences between central power plants and wellhead power plants $[2,56]$

\begin{tabular}{llll}
\hline & Parameters & Central power plant & Wellhead power plant \\
\hline 1 & Setup period & Takes more than 2 years to set up & Takes between 3 and 6 months \\
2 & Customization & Not site specific & Customized to specific site conditions \\
3 & Number of wells & Fed by multiple steam wells & Normally operate on a single well \\
4 & Capacity factor & Higher capacity factor & Lower capacity factor \\
5 & Operating efficiency & Higher efficiency & Lower efficiency \\
6 & Power evacuation & High voltage & Can use low voltage \\
7 & Non-condensable gases & Well dependent & Well dependent \\
8 & Flexibility and portability & Not flexible and not portable & Flexible and portable \\
9 & Specific steam consumption & Low specific steam consumption & High specific steam consumption \\
\hline
\end{tabular}

compared to central power plants [56]. This reduces the pollutant density over the power plant area, but the overall environmental impact remains the same [2].

\section{Summary of differences between wellhead and central power plants}

The differences between central power plants and geothermal wellheads are summarized in Table 2 .

\section{Permanent versus mobile geothermal wellheads plants}

\section{Mobile geothermal wellhead plants}

Wellhead power plants could be used by investors to realize early electricity generation and revenue from productive wells while steam field development is still progressing $[2,5,38]$. In this case, ease of shutdown and relocation in terms of time is very important. The downtime is influenced by the technology used and thus the power plant's complexity. To minimize the downtime of the plants, civil engineering works for the new sit should be ready before dismantling of the old plant takes place [43].

\section{Wellhead power plant decommissioning and relocation}

During wellhead decommissioning and relocation, significant activities, according to [56], include:

i. The wiring between the various pieces of equipment has to be removed.

ii. Internal wiring within cubicles and between cubicles in the electrical container and on the turbine/ generator should be portable.

iii. The pipes are disconnected at the flange connection or are cut into smaller portable pieces.

iv. Insulation is removed during dismantling and replaced during assembly.

v. The equipment in the steam supply has to be looked into when relocation is considered, espe- cially as it is not a given that the pipes and equipment can be utilized at the new location, for example, control valves at the brine site depend heavily on the enthalpy of the well.

\section{Comparison of relocation time and downtime between wellhead technology options}

The time required to relocate a wellhead power plant of $5 \mathrm{MW}$ was as follows for three basic generation technologies, according to [4].

From Table 3 it can be noted that the back pressure plants are the simplest and fastest to move followed by the condensing power plants, while the binary power plants are the most complex and difficult to stop, dismantle, relocate and reassemble. Therefore, if the wellhead power plants are temporary and are being used for quick or temporary power generation, for example, for emergency or steam field development, then the back pressure wellhead plants offer the best solution in terms of quick delivery and shorter relocation time.

The time estimates assume that the plant design and layout is not changed. Table 3 shows that it will take between 6 months for back pressure plants and 11 months for binary plants to be decommissioned, moved and reconnected to a wellhead power plant at a different site, depending on the complexity of the technology used. This duration includes the time for

Table 3 Comparison of condensing, back pressure and binary wellhead plants $[2,4]$

\begin{tabular}{lll}
\hline Generation technology & $\begin{array}{l}\text { Relocation time } \\
\text { (months) }\end{array}$ & $\begin{array}{l}\text { Downtime } \\
\text { (months) }\end{array}$ \\
\hline Condensing power plants & 6 & 3 \\
Back pressure power plants & 4 & 2 \\
Binary power plants & 7 & 4 \\
\hline
\end{tabular}


dismantling the plant, moving it to a new site and assembling and testing it at the new site.

\section{Design and construction of wellhead plants Wellhead power plant description}

A wellhead power plant consists of the following main systems and elements:

i. Steam system, i.e., the hot and cold ends.

ii. Turbine and generator set.

iii. Electrical and control system.

iv. The production well.

v. Instrument and control systems.

The plant consists of a turbine generator unit that operates on one single steam and condensing system [2]. Figure 9 shows the main components of a wellhead power plant.

Figure 9 shows the main elements of a wellhead power plant, namely, the cooling towers, generators, control containers, production well, steam piping, silencer, separator and the turbine, which is coupled to a generator.

\section{Technical features of wellhead power plants} Characteristics of wellhead power plants

According to $[5,54,60]$, the characteristics of wellhead power plants include the following:

i. The plants can be activated without auxiliary power except for battery banks for instrumentation and control operations as they have turbine-driven oil pumps and mechanical-hydraulic controls. ii. They are an attractive investment as investors can quickly realize the cash flow during the project development phase.

iii. They can guarantee optimum electricity from the prevailing specific well conditions as the wellhead plant operation can be made unique to the characteristics of the well-used, hence maximum electricity generation can be realized.

iv. With geothermal wellheads, rapid deployment of geothermal electricity is possible as modularized preassembled units are used, which significantly reduce the lead times.

v. Wellheads reduce risks as the plants are small and in the case of plant failure, they can be quickly decommissioned and moved to another site. This reduces failure risks for investors.

vi. Reduced costs of electricity are seen since wellheads are designed to specific well conditions which can be optimized for higher generation based on the prevailing well conditions. Together with simplicity and ease of operation and maintenance, the overall cost of generation is reduced.

vii. There is reduced pollution from using the wellheads as electricity from the wellheads can be used for field operations like drilling which displaces diesel generators. As an example, the Menengai wells 03 and 04 in Kenya used US \$ 1.2 million in the form of diesel and related equipment, which was about $25 \%$ of the cost of the wells.

viii. Quick development is possible with wellheads. The Green Energy Group estimated that a central plant takes about seven years to complete while it takes

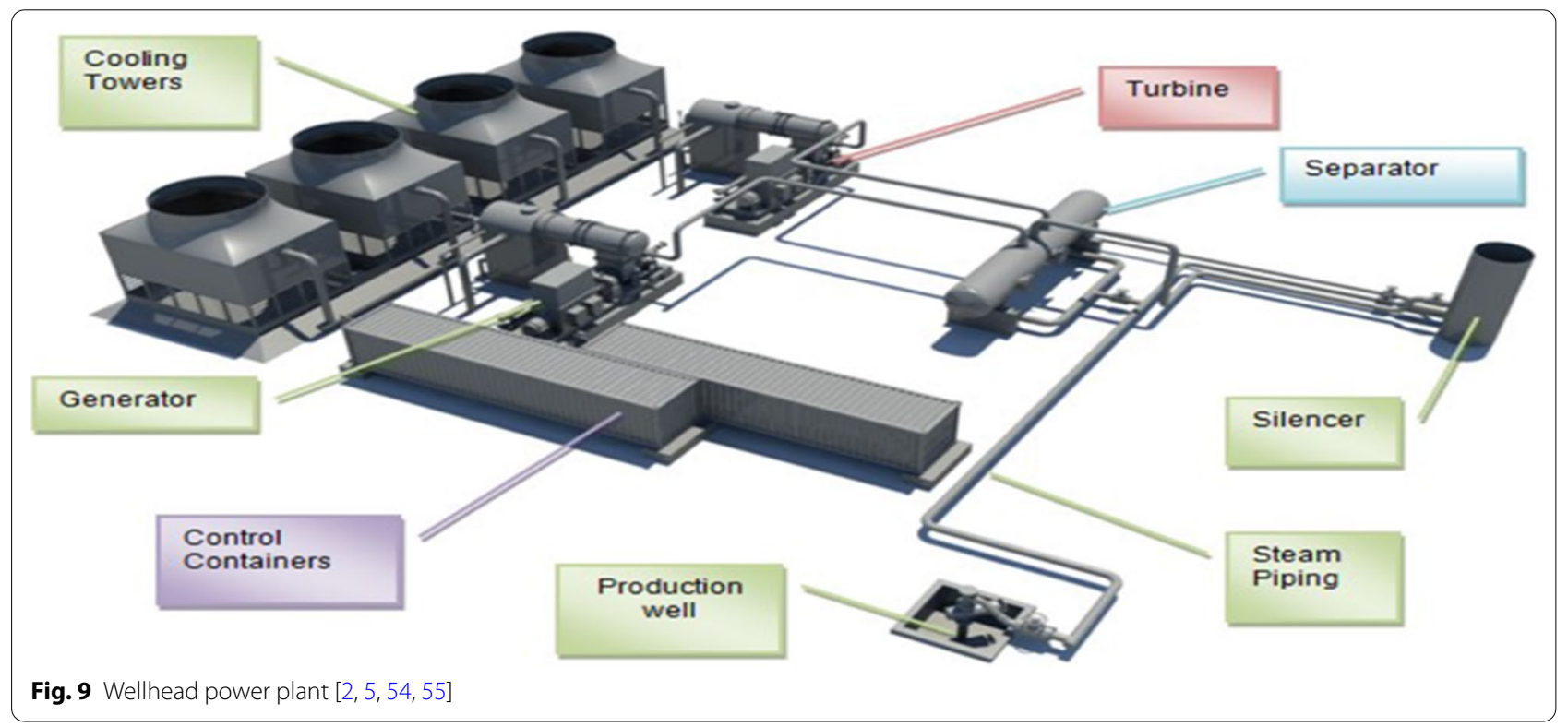


about one year to design and install a wellhead plant of up to $15 \mathrm{MW}$ capacity. This significantly reduces the time between exploration and revenue generation.

ix. Wellhead plants can lead to integrated investment as they can be incorporated with other economic activities like manufacturing and farming, leading to higher benefits compared to central power stations which are complex and cannot easily be incorporated with other economic activities.

x. Wellhead power plants are easy to transport, install and commission.

xi. Wellhead power plants have higher efficiency, capacity factors and reliability compared to other power plants like diesel power plants, but have lower efficiency than central geothermal power plants.

\section{Technology options in wellhead and central power plants}

There are three basic types of work cycles that can be applied in electricity production in geothermal wellhead power plants. They are condensing, back pressure and binary (ORC) just like in central power plants.

\section{Flash power plants}

Flash technology is used whenever the geothermal fluid consists of a mixture of liquid/water and vapor/steam [5]. Flash steam plants are the most common power plants globally and are preferred where fluid temperature range between 150 and $180^{\circ} \mathrm{C}$. In these plants, the geothermal fluid from the production well is flashed to steam in a flash tank/vessel and the resulting dry steam is directed to the turbine and then to the condenser [61].

\section{Condensing (single flash) plant}

This technology is adopted for a liquid-dominated geothermal system $[5,60]$. In these plants, a two-phase fluid is piped from the production well to the steam separator where the liquid fluid is separated from the steam. The liquid is then directed to a reinjection well. The steam then flows from the separator to the steam turbine which turns it as it expands through the turbine and, by so doing, rotates the generator coupled to it to generate electricity. The exhaust steam goes to the condenser where it is condensed to water with heat transferred to the condenser coolant which is normally circulating water. The cooling tower is used to cool the condenser water [56]. The separated water, or brine may be reinjected to the underground pipes through a reinjection well [60].

A typical example of a successful single-flash wellhead plant is in Naivasha, Kenya, where the Oserian Development Company, which is a horticultural flower company, in collaboration with the Kenya Electricity Development Company and the Green Energy Group company, developed a 5-MW wellhead plant in 2012 which is currently still operational [60]. Figure 10 illustrates a single-flash power plant.

Figure 10 shows the main elements of a flash steam plant with production well, separator, steam turbine condenser and condensate pump. The reinjection well is included, but some wellhead power plants do not have reinjection facilities [2].

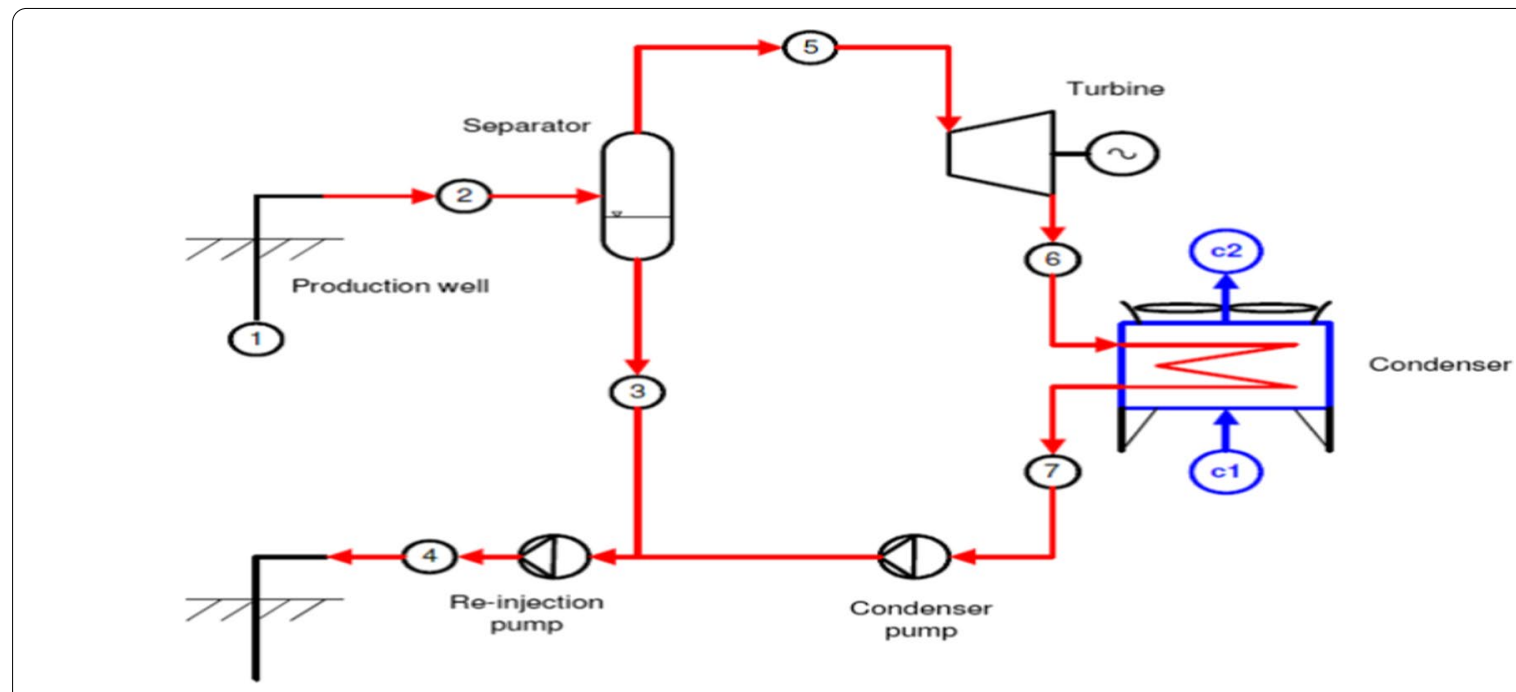

Fig. 10 Single-flash power plant [62] 


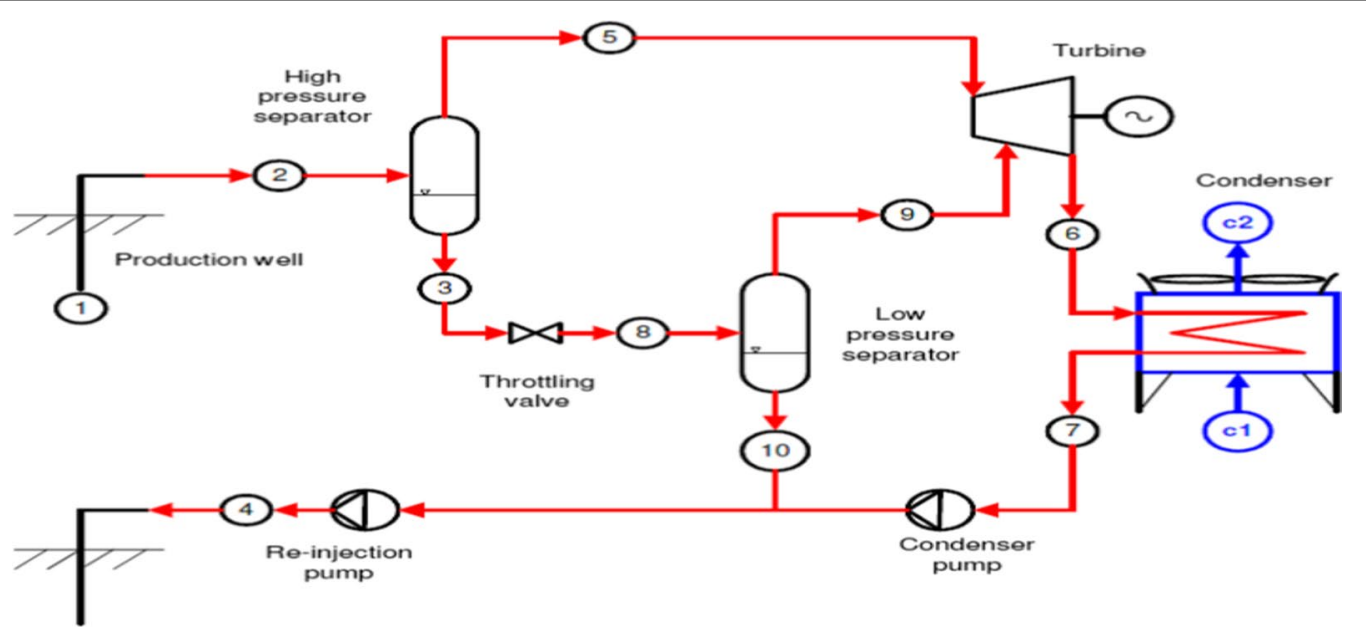

Fig. 11 Double-flash wellhead system [62]

\section{Double-flash wellhead system}

In double-flash wellhead systems, two stages of flashing are done in two different separators operating at different pressures, one after the other, to produce steam at different pressures that is then introduced into the turbine at different stages of the turbine blades [5]. Figure 11 illustrates a double-flash geothermal system.

Figure 11 shows the system with one production well and one reinjection well but with two steam separators operating at high and low pressure interconnected with flash steam from both separators being directed to a steam turbine at different stages in the steam turbine.

According to [63], flash-type plants were ideal for corrosive steam, but the turbine had to conform to a high level of technology and was hence expensive. According to [58], flash plants were historically used for temperatures in excess of $150{ }^{\circ} \mathrm{C}$, but [64] observed that flash technology could be employed for temperatures as low as $110^{\circ} \mathrm{C}$.

\section{Back pressure wellhead plants}

The back pressure wellhead power plant makes use of a back pressure steam turbine that vents into the atmosphere [56]. According to [62], the back pressure system was simple in construction and cheaper, but had lower thermal efficiency and was preferred in multiple use applications such as CHP applications and applications where energy efficiency was a priority. They could generally be used for resources at temperatures between 200 and $320^{\circ} \mathrm{C}$ [5]. The cost of back pressure power plants is much lower than condensing power plants. In terms of efficiency, since steam is not condensed, it has much more energy at the turbine exit, hence lower conversion efficiency [56]. Figure 12 illustrates a back pressure wellhead generation system.

The main feature of the back pressure turbine system as shown in Fig. 12 is that steam exhausting from the turbine is released into the atmosphere through an atmospheric exhaust device/system.

\section{Organic Rankine cycle (binary) and Kalina cycle}

Binary plants are designed to operate with two cycles: a geothermal fluid loop and a power cycle loop, which can be either the ORC or the Kalina cycle. The technology is commonly adopted for all liquid geothermal fluids or medium-low temperature geothermal resources generally lower than $150{ }^{\circ} \mathrm{C}[5,61]$.

In binary power plants, a low-temperature boiling fluid is heated and evaporated in the vaporizer and preheater and directed to the steam turbine. The secondary fluid exits the turbine at a lower pressure after expansion in the turbine and goes to the condenser where it is condensed. In the Kalina cycle a mixture of $70 \%$ ammonia and $30 \%$ water is used as the working fluid and has the potential for better energy efficiency compared to the Rankine cycle [19]. The Kalina cycle is a modified Rankine cycle with distillation/separator and absorption/recuperator components invented by Alex Kalina in the 1980s. Kalina cycle plants are safe, have lower capital cost and are simpler in construction and can work in small power plants as well as conventional plants of 50-100 MW. With optimization [36], the Kalina cycle is more efficient and yields up to $14.7 \%$ more power than the Rankine cycle $[35,36]$.

A feed pump circulates the condensed binary fluid to the preheater where it is vaporized. The geothermal 


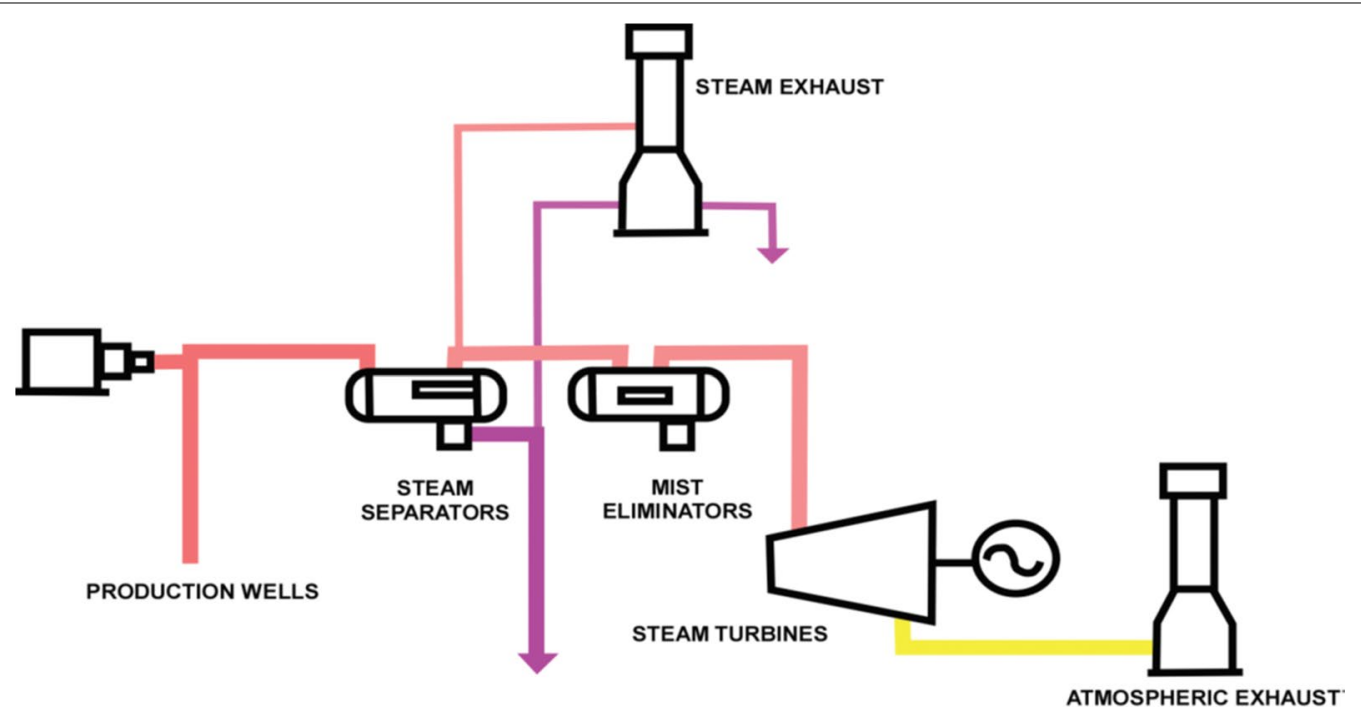

Fig. 12 Typical back pressure turbine/generator conversion system [62]

fluid may be re-injected back into the reservoir via the reinjection well. Cooling has to take place in the condenser and this is affected by either water (wet cooling) or air (dry cooling). Therefore, heat transfer takes place in the preheater, evaporator and condenser [56]. In the preheater, heat from the turbine exhaust is passed to the working fluid before it goes to the evaporator as the exhaust then moves to the condenser where the cooling water or air extracts the remaining heat. Figure 13 illustrates an organic Rankine cycle wellhead plant.
Figure 13 shows the organic Rankine cycle with the main elements being the production and reinjection wells, the feed pumps for cooling the water and organic fluids, the condenser, the preheater and the turbine generator set.

According to [63], binary power plants use a lowtemperature boiling medium like pentane which might be flammable hence risky, have higher piping requirements and incur higher operation costs. A common configuration of binary cycle plants uses a submersible pump which guarantees stable geothermal well

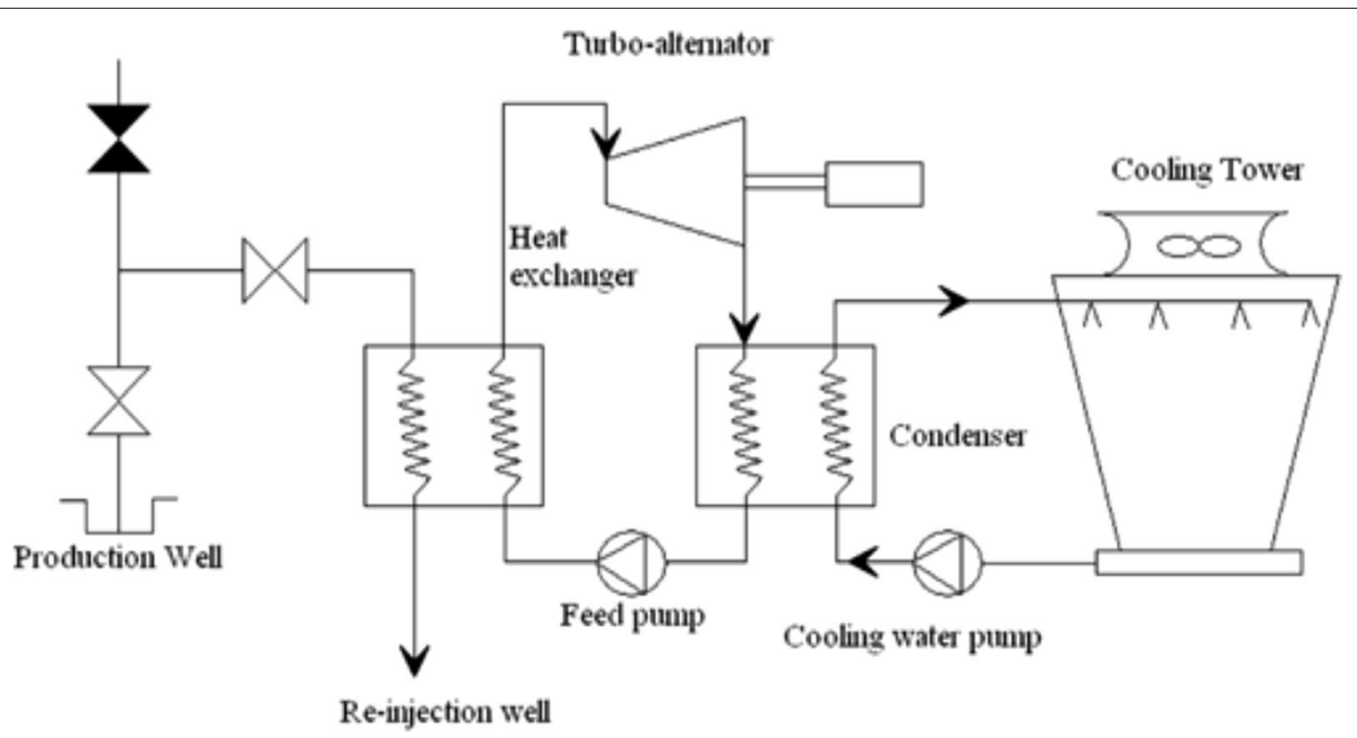

Fig. 13 The organic Rankine cycle [63] 
production but is affected by scaling, cavitation and corrosion and hence the pumps have a short lifespan $[61,63]$.

Binary plants can be used for low enthalpy steam or the liquid phase from the separator or waste heat from the steam turbine [65]. The challenge remains high operation and maintenance costs, and high initial costs. Wellhead and central power plants could both apply the organic Rankine cycle technology plants [53].

\section{Choice of technology}

For wellhead power plants, the choice of technology is influenced by:

i. The enthalpy and temperature of the geothermal fluid.

ii. The cost of technology with back pressure being the cheapest and ORC and Kalina cycle plants being the most expensive.

iii. Availability of financing with respect to the cost of technology chosen.

iv. Application of the wellhead, i.e., temporary or permanent application. More efficient and expensive technology is ideal for central power plants and permanent wellhead power plants.

v. Expected duration of operation, simple and cheap option is ideal for power plants needed for a shorter period $[2,5]$.

\section{Geothermal wellhead plants and the socio-economic impact}

Geothermal power generation is associated with some negative impacts to the environment caused by noncondensable gas emissions, brine effluents and other undesirable audio-visual effects from the power plant construction and operation processes. According to [56], geothermal steam pipelines and power transmission lines had some negative visual impacts on the environment. The emissions in the form of $\mathrm{CO}_{2}$ and $\mathrm{H}_{2} \mathrm{~S}$ happened to be the same for geothermal wells regardless of the generation mode or the technology used in electricity generation. However, for wellhead power plants, the emissions were distributed over a wider geographical area compared to central power plants, hence reducing the density of pollutants from geothermal fluid around the power plant.

Geothermal wellhead plants like the central power plants have negative environmental consequences. According to $[47,48]$, one of the challenges of operating wellhead power plants was the venting of geothermal fluid from the production well whenever the turbine tripped. This had environmental consequences such as silica deposits as witnessed at the Eburru wellhead power plant which led to conflict with the surrounding community.

\section{Conflict and stakeholder engagement}

All power projects should be subjected to an environmental and social impact assessment. This calls for early engagement with the community as well as continuous engagement during the project execution phase. This would make it possible to control issues that would usually arise. Several stakeholder engagement strategies should be used and these include workshops, consultative meetings, exchange visits, public presentations and hearings and participatory research processes [66]. These techniques could be used to generate information and provide facts and also to resolve any conflict that might arise in the course of the project planning and execution phases. All stakeholders should therefore be identified by carrying out the stakeholder analysis so as to determine their interests, whether a central or wellhead project was being developed [47]. This discussion implies that both wellhead power plants and central power plants have negative social and environmental impacts which should be addressed for successful project implementation.

\section{Operational challenges of wellhead power plants}

Greenhouse gas emissions and global warming have the greatest environmental impact that should be considered in the design and operation of all power plants [8]. The concerns over global warming and other environmental challenges like acid rain have prompted the commitment to reduce reliance on fossil fuels $[67,68]$ in exchange for renewable sources of energy [69]. Wellhead power plants, just like central power plants, were associated with significant issues and challenges. Successful utilization of geothermal resources for electricity generation was dependent on the existence of few or no emissions and efficient conversion technologies [61]. According to [70], unsustainable geothermal extraction practices previously caused several environmental issues such as land subsidence and the disappearance of geysers in New Zealand [5]. In Kenya blow-offs occasioned by frequent trips at the Eburru wellhead plant led to conflict with the local farmers due to deposits from the geothermal wellheads [48].

Apart from operational challenges like trips which often lead to a blow-off and hence pollution, non-condensable gases present a significant environmental challenge except for organic Rankine technology where the gases are confined in the fluid loop and re-injected back through the reinjection well. The use of a gas extraction system would allow a condenser to operate although $\mathrm{CO}_{2}$ 
is still often emitted into the surroundings. An effort should be made to capture or isolate the non-condensable gases which pose an environmental pollution threat from both the wellhead and central power plants [61].

Therefore, the operation and maintenance of geothermal wellhead power plants brings environmental challenges which must be addressed by the developers in close collaboration with stakeholders. These challenges are brine effluent, noise pollution, a repugnant smell from $\mathrm{H}_{2} \mathrm{~S}$ and deposits on crops. Investment in technology to trap the non-condensable gases is important while reinjection, besides managing pollution, leads to sustainable geothermal resource management $[2,54]$. The several plant trips raise concerns about the technical viability of the geothermal wellhead technology as they impact both the reliability and capacity factor of the power plant.

\section{Feasible applications of wellhead vs central power plants}

Various studies have made suggestions about the circumstances under which wellhead power plants or central power plants are more feasible in geothermal electricity generation. These may vary from steam field to steam field $[4,58]$. Notable applications included:

\section{i. Cost of steam gathering systems}

The most costly item in the steam gathering system is the pipelines, where the length of pipeline required is a significant factor, while the terrain might influence the design, pumping requirements and transmission losses along the way between the wells and the power plant. Where the terrain is rough and the wells too far apart from one another, it might be technically and economically more feasible to develop permanent wellhead plants as opposed to central power plants. On average the cost of gathering steam was about US\$250/kW [4, 71].

ii. Time difference between commissioning of wellhead plant and central power plant delivery

The time difference between the commencement of a geothermal power project and the power plant commissioning is an important factor in deciding whether to invest in a wellhead power plant or the direct development of a central power plant without the option of using wellhead generators. Where the time period is long, a wellhead power plant becomes an attractive option, but where the delivery time is reduced or is significantly lower, then direct development of a central power plant would be more attractive than the wellhead power plant option in the case of temporary wellhead development model $[4,72]$. iii. Wellhead plant technology options

The choice between the various wellhead power plant technologies is also considered important in wellhead power plant development. In general, where the time delivery period was longer than 12 months, a condensing turbine wellhead plant offered the best cost benefit solution while the binary cycle plants offered the highest power output per unit of steam but required higher investment capital $[4,5]$.

iv. Wellhead power plant in early stages of project

In this development model, wellhead power plants are installed on a temporary basis on each well after it has been drilled and tested, with separation pressure being specific and unique to each well. In this development model, back pressure, condensing and extraction turbine technology could be selected. The technology selected should optimize generation and cost, with the salvage value of the wellhead power plant being a guiding principle. Binary plants would give more power at higher cost while back pressure turbine plants would give less power at lower cost per unit of power produced [4, 5].

v. High-enthalpy geothermal fluid

For geothermal wells with high-enthalpy fluid, wellhead power plants provide a more feasible solution for almost all scenarios including the technology adopted, separator pressure, payback period and time difference analysis $[4,5,72]$. Therefore, wellhead plants should be considered for wells with high-enthalpy geothermal fluid for optimized generation.

vi. Low-enthalpy steam

Low-enthalpy wells pose a challenge to central power plant development because they lower the effective separation pressure to their low levels. They therefore reduce the contribution of high enthalpy and high pressure wells to the electricity generation which is limited to separator pressure. On the other hand, increasing separator pressure to correspond to high pressure and enthalpy wells cuts out the supply from low-pressure wells rendering them useless in the generation system $[2,4]$.

It is worth noting that for geothermal fluids with high enthalpy, the recommended optimized separator pressure might be higher than what the current equipment in the market could handle, hence the need for further development in wellhead technology equipment for wider application and adoption $[2,4,71,72]$. 


\section{Research findings}

This study came up with the following findings on wellhead power generation technology with respect to the conventional wellhead electricity generation setup:

i. Specific steam consumption is relatively lower in central power plants than in geothermal wellhead power plants, hence there is more steam economy and power output per unit steam output.

ii. The organic Rankine cycle is the most efficient although more costly system in both central and wellhead power generation, but may not be the best for short period temporary wellheads due to the higher delivery and disassembly time required.

iii. Where a geothermal field has significant variation in well characteristics for all successful wells drilled, wellhead plants become a more feasible option than a central power plant as they lead to optimum resource utilization since they help optimize generation to specific well characteristics.

iv. It is technically feasible to have a mixed field development where both central power plants and wellhead plants are used based on the varying characteristics of geothermal steam fields and individual wells.

v. The cost of back pressure wellhead technology is lower than condensing and ORC technology, but it is an inferior technology option in wellhead power generation.

vi. The gaseous emissions like $\mathrm{CO}_{2}$ and $\mathrm{H}_{2} \mathrm{~S}$ from a geothermal well are constant regardless of whether they are connected to wellhead plants or central power plants. However, for wellheads, these gases are dispersed over a wider area since the plants are widely spread over the entire steam field as opposed to a central power plant where gases from all the wells are emitted from a central point.

vii. For geothermal fields with significant variation in well characteristics, wellhead power plants can be used on a permanent basis to ensure optimum generation from a geothermal steam field by optimizing generation from specific wells based on the well's unique prevailing characteristics.

viii. The central geothermal power plant has higher overall efficiency than the wellhead power plants, leading to lower specific steam consumption and better resource utilization.

ix. The specific steam consumption of a central power plant is lower than the specific steam consumption of wellhead power plants for steam with similar properties.

x. For countries with stringent environmental regulations like Japan, which has significant geothermal resources in protected national parks, the use of wellhead power plants is recommended as opposed to central power plants since they will have less environmental impact from pipelines, and well emissions which are dispersed.

xi. Reinjection of used geothermal fluid becomes a challenge with geothermal wellhead plants and a solution is to pipe the fluid to a reinjection well which is costly, especially where only one well exists.

xii. The operation and control of several wellhead plants in a geothermal field is more demanding than a central plant since each wellhead has to be separately operated and controlled in addition to a combined monitoring system for all wellhead plants in a field.

xiii. A geothermal field with several wells leads to a network of several transmission lines in the field which can have a negative visual impact similar to the one caused by streamlines in the case of central power plants.

xiv. Wellhead power plants often operate at low voltage, which facilitates connection to the electricity distribution grid, making decentralized generation possible. This, however, makes the generation susceptible to consumer demand changes affecting generation and may cause trips during power surges. This reduces the reliability and efficiency of electricity generation and leads to steam blow-off whenever the plant trips, causing ecological pollution.

xv. Wellhead plants can be used as either temporary or permanent plants. Where they are used as temporary plants, relocation time is an important consideration with back pressure turbine plants being the quickest and binary plants being the slowest to relocate as they are more complex in construction. This also influences the viability of the project and the overall project cost, hence the need for proper selection.

xvi. Whereas wellhead power plants can be found in sizes of 1 to $15 \mathrm{MW}$, the minimum practical size based on economic consideration is 3-5 MWe. However, the specific well characteristics may influence the size and the technology used for proper plant sizing.

xvii. Manifolding, or tying together wells with different pressures, forces the high-pressure wells to blow off excess energy and pressure in central power plants. This problem can be solved by using wellhead power plants which maximize the use of prevailing well-specific conditions, hence leading to optimized generation. 
xviii. Atmospheric venting occasioned by wellhead plant trips or rapid loss of load, hydrogen sulphide gas odor, noise pollution and brine effluent disposal are the leading environmental concerns about geothermal wellhead power plant operations. These emissions are also characteristic of central power plants.

xix. Most wellhead and small geothermal power plants do not use reinjection wells. Whereas this would reduce costs, it compromises the overall sustainability of resource use in the long term.

\section{Conclusion}

The long gestation period and high upfront costs and risks in the development of central geothermal power plants are the main reasons for the slow rate of geothermal electricity growth and contribution to the total electricity mix globally. Between 2005 and 2019, the growth in global geothermal electricity capacity was about 6714 MWe, representing an average annual increment of geothermal generating capacity of $447.60 \mathrm{MW} /$ year, which was an average annual growth of about $5.15 \%$. Geothermal power plants can be developed either as conventional central power stations or wellhead power plants. Wellhead plants can be developed as temporary or permanent plants. Where wellhead power plants are used on a permanent basis, they are a better option for steam wells with too low or too high pressure compared to others in the steam field. In the temporary application model, wellhead power plants generate more benefits where there is more time in respect of the time difference from the moment a wellhead power plant could start to produce electricity compared to the moment a central power plant could start to produce electricity. Where the time period to develop a central power plant is shorter than 1 year, it may not be beneficial to use wellhead power plants instead of central power plants for temporary application model.

Both central and wellhead plants have a relatively higher capacity factor than other power plants and so can be used to supply base load electricity for the grid or decentralized power supply. Wellhead power plants are becoming more attractive because they come as factory-built modules that are simple and quick to construct, leading to shorter project lead times compared to conventional central power stations. Their simplicity and modularity, however, affects their generation efficiency and ultimately the use of available geothermal resources as they are relatively less efficient. Wellhead power plants can be used in either temporary or permanent mode, which ultimately influences the selection of the most appropriate wellhead technology. As for central power plants, the main considerations are the steam characteristics, availability of technology and the cost of the technology and its affordability. Since portable geothermal wellhead plants are assembled on a common base, then shipped to the site, the result is reduced installation and modification work, thus making it cheaper and faster to install, commission and decommission the plants. These generally reduces the unit cost of investment and hence power from wellhead power plants.

Wellhead and central power plants use the same technologies except that wellhead plants are smaller in size and may have some features such as reinjection wells missing. Wellhead plants have lower efficiency and higher specific steam consumption (SSC) compared to central power plants. To improve on their efficiency and availability, combined steam and power application is encouraged in the form of combined heat power plants (CHP). The geothermal heat application includes agriculture and industrial process use such as distillation and district heating. There is a need to develop policy initiatives that will address the technical, financial, environmental and legal initiatives that will accelerate geothermal electricity generation by incorporating wellhead plants in the project's execution cycle and address the challenges facing the technology and overall geothermal energy development. This may include legislation on the reinjection of geothermal fluids for small wellhead plants, and other environmental and sustainability concerns, which require external enforcement to succeed.

The use of both wellhead and central power plants is feasible technically, environmentally, socially and economically and they can complement one another depending on the prevailing conditions of the steam field. Wellhead power plants could facilitate a reduction in the capital cost of projects, a reduction of development risks, quick revenue and an attractive return on investment. Whereas wellhead power plant units exist with capacity up to $15 \mathrm{MW}$, recent developments have drilled high enthalpy wells of wellhead pressure much more than $15 \mathrm{MW}$. Therefore there is need to develop wellhead units with high pressure denominations for use on such wells to avoid wastage of steam and capacity.

\section{Policy implication and recommendations}

Although a straight economic comparison between wellhead power plants and central power plants has indicated that wellhead plants may not compete favorably, they possess unique and desirable characteristics which can offset their economic and technical disadvantages. These desirable characteristics include reusability, low capital investment, portability, and rapid power production ability. Further research into the economic viability of wellhead power plants need to be done to quantify the 
benefits. The design of wellhead power plants needs to take into account noise pollution, reinjection of fluid and hydrogen sulphide's repugnant smell which are the main environmental concerns for operating wellhead power plants such as the one at Eburru in Kenya, although similar challenges can affect central power plants. More studies on the long-term viability of wellhead plants in respect of technical, environmental and financial terms are recommended, especially in respect of long term/permanent application to ascertain their sustainability compared to central power plants.

Generally, investors and policy-makers in geothermal electricity projects should consider the use of wellhead plants as the predecessors of central power plants for early revenue and electricity generation. They should also consider whether a temporary application or a permanent application is preferable, where restrictions such as environmental regulations exist or there is too much variation in wellhead pressures as well as other important characteristics of the various wells in a steam field. However, for long-term investment decisions, there is a need to carry out more detailed techni$\mathrm{cal}$, financial/ economic and environmental feasibility studies. This implies that at the project initiation and design stages, both central and wellhead power plants should be given due consideration so as to address the feasibility and sustainability issues of geothermal electricity projects. On the technology side, there is need to design and develop wellhead power plant units with much higher capacity beyond what we have currently in the market since wells with pressure greater than 15 MW have become a common occurrence in some steam fields.

\section{Abbreviations \\ GEG: Green Energy Geothermal; KenGen: Kenya Electricity Generating Com- pany PLC.; ORC: Organic Rankine cycle; CHP: Combined heat and power; SSC: Specific steam consumption; MWe: Megawatt electricity; MWth: Megawatt thermal.}

\section{Acknowledgements}

The authors wish to express their appreciation to the reviewers, researchers and scholars in the field of geothermal energy and electricity for providing readily accessible, significant, credible and reliable information in all aspects of geothermal energy. This made the production of this study successful.

\footnotetext{
Authors' contributions

The first author drafted the manuscript without any third party assistance under guidance of the second author. Considerable insight into the application of wellheads under varying conditions was provided from a wide variety of primary and secondary data. The first author was also guided by his own experience as an engineer in power generation in terms of design, operation and maintenance. The second author reviewed the manuscript and made improvements and additional theoretical contributions including coordination of editing and other publishing related expenditures. Both authors read and approved the final manuscript.
}

\section{Funding}

No funding was provided for this research and the whole exercise was fully funded by the researchers.

\section{Availability of data and materials}

The research has provided all the data and information used and did not use any undeclared data and information. Moreover, any datasets used and/or analyzed during the current study are available from the authors on reasonable request.

\section{Declarations}

Ethical approval and consent to participate Not applicable.

\section{Consent for publication}

The authors have the authority to publish the research work in any publication.

\section{Competing interests}

The authors declare that they have no conflict of interest in this research.

Received: 18 January 2020 Accepted: 4 March 2021

Published online: 20 March 2021

\section{References}

1. Sanya SK (2013) Geothermal power capacity, sustainability and renewability. In: Kaltschmitt MT, Bronicki NJ, Söder LY, Vega LA (eds) Renewable energy systems. Springer, New York . https://doi.org/10.1007/978-1-46145820-3_229

2. Kabeyi MJB (2020) Feasibility of wellhead technology power plants for electricity generation. Int J Comput Eng Res Trends 7(2):1-16. https://doi. org/10.22362/ijcert/2020/v7/i02/v7i0201

3. Kabeyi MJB, Oludolapo AO (2020) Characteristics and applications of geothermal wellhead powerplants in electricity generation. Presented at the SAllE31 proceedings, South Africa, 5th-7th October 2020, Virtual event, 4422. https://www.dropbox.com/s/o0sj1 108v8n9sgh/SAllE31\% 20Conference\%20Proceedings.pdf?dl=.

4. Geirdal CAC, Gudjonsdottir MS, Jensson P (2015) Economic comparison of a well-head geothermal power plant and a traditional one. Geothermics 15(2015):1-13. https://doi.org/10.1016/j.geothermics.2014.04.003

5. Kabeyi MJB (2019) Geothermal electricity generation, challenges, opportunities and recommendations. Int J Adv Sci Res Eng 5(8):53-95. https:// doi.org/10.31695/IJASRE.2019.33408

6. Kabeyi MJB, Oludolapo AO (2020) Managing sustainability in electricity generation. Presented at the 2020 IEEE international conference on industrial engineering and engineering Management, Singapore, Singapore, 14-17 December 2020, IEEM20-P-0406. https://ieeexplore.ieee.org/ document/9309994

7. Rahman S, Castro A (1995) Environmental impacts of electricity generation: a global perspective. IEEE Trans Energy Convers 10(2):307-314. https://doi.org/10.1109/60.391897 (in English)

8. Günkaya Z, Özdemir A, Özkan A, Banar M (2016) Environmental performance of electricity generation based on resources: a life cycle assessment case study in Turkey. Sustainability 8:1097. https://doi.org/10.3390/ su8111097

9. Liu XM, Wei M, Yang LN, Wang X (2017) Thermo-economic analysis and optimization selection of ORC system configurations for low temperature binary-cycle geothermal plant. Appl Therm Eng 125:153-164. https://doi. org/10.1016/j.applthermaleng.2017.07.016

10. IEA. Geothermal power generation in the sustainable development scenario, 2000-2030. International Energy Agency. https://www.iea.org/ reports/geothermal. Accessed 2020

11. Axelsson G (2016) Nature and assessment of geothermal resources. Presented at the SDG short course i on sustainability and environmental management of geothermal resource utilization and the role of geothermal in combating climate change Santa Tecla, El Salvador. https://orkus tofnun.is/gogn/unu-gtp-sc/UNU-GTP-SC-22-04.pdf 
12. Quick H, Mechael J, Huber H, Arslan U (2010) History of international geothermal power plants and geothermal projects in Germany. Presented at the proceedings world geothermal congress 2010, Bali, Indonesia

13. European Commission. Blue book on geothermal resources. European Commission. http://www.geoelec.eu/wp-content/uploads/2012/04/EUBlue-Book-Geothermal-2000.pdf. Accessed 2020

14. Lundin J, Lundin U, Leijon M. EUSUSTEL-WP3 report- Geothermal power production. Uppsala University. https://www.academia.edu/30759059/1_ EUSUSTEL_WP3_Report_Geothermal. Accessed 2020.

15. ENISCUOLA. Brief history of geothermal energy. http://www.eniscuola. net/en/2016/11/18/brief-history-of-geothermal-energy/. Accessed 2020

16. Kepinska B. Geothermal energy in human history, culture, and practices — selected highlights. United Nations University. http://www.os. is/gogn/flytja/JHS-Skjol/UNU\%20Visiting\%20Lecturers/Beata01.pdf. Accessed 2020

17. BP. Statistical review of world energy 2012. BP. https://www.laohamutuk. org/DVD/docs/BPWER2012report.pdf

18. Karytsas C, Mendrinos D. Global geothermal power market. Presented at the European Geothermal Congress, Pisa, Italy 2013. https://www.resea rchgate.net/publication/258926033_Global_Geothermal_Power_Market

19. Koroneos C, Rovas D (2013) Energy analysis of geothermal electricity using kalian cycle. Int J Energy 12(1):54-69

20. Alshareef AS (2017) Technology assessment model of developing geothermal energy resources for supporting electrical system: the case for Oregon, Dissertation, Paper 3515. https://pdxscholar.library.pdx.edu/ open_access_etds

21. Lund JW. Characteristics, development and utilization of geothermal resources. GHC Bull. https://pdfs.semanticscholar.org/084d/ecf2a958f3 5fa125251181253401600a5708.pdf

22. Bertani R (2010) Geothermal power generation in the world 2005-2010 update report. Presented at the proceedings World Geothermal Congress 2010, Bali, Indonesia, 25-29 April 2010. https://www.geothermal-energy. org/pdf/IGAstandard/WGC/2010/0008.pdf

23. Leeds WM, Evensizer J (2020) A market survey of geothermal wellhead power generation systems: report for Jet Propulsion Laboratory. California Institute of Technology Pasadena. https://www.geothermal-energy.org/ pdf/IGAstandard/WGC/2010/0605.pdf. Accessed 2020

24. Esipisu I (2019) Before renewable power plant is completed, Geothermal Overtakes Hydro in Kenya. http://www.ipsnews.net/2015/ 10/before-renewable-power-plant-is-completed-Geothermal-overt akes-hydro-in-kenya/

25. Sutter J, Kipyego E, Mutai D. The use of portable geothermal wellhead generators are small power plants to accelerate geothermal development and power generation in Kenya. GHC Bull. https://pdfs.semanticsc holar.org/2ccf/ea5912930aa49a2246d235105cbaacb7672b.pdf

26. Kabeyi MJB (2018) Michael porter's five competitive forces and generic strategies, market segmentation strategy and case study of competition in global smartphone manufacturing industry. Int J Appl Res 10(4):39-45. https://doi.org/10.13140/RG.2.2.12388.01922

27. Sönnichsen N. Worldwide capacity of geothermal energy 2009-2019. Statista. https://www.statista.com/statistics/476281/global-capacity-ofgeothermal-energy/. Accessed 29 Aug 2020

28. Ritcher A (2019) Fang geothermal plant in Chiang Mai, model for more to come in Thailand. In: Think Geoenergy, vol 2020

29. Ritcher A (2020) 2020 to become a milestone year for the global geothermal energy sector, vol 2020

30. IEA. Global energy review 2020. International Energy Agency. https:// www.iea.org/reports/global-energy-review-2020/renewables. Accessed 2020.

31. IEA (2020) Renewables information: overview. International Energy agency. https://www.iea.org/reports/renewables-information-overview. Accessed 10 Oct 2020

32. IRENA. Geothermal power: technology brief. https://www.irena.org/-/ media/Files/IRENA/Agency/Publication/2017/Aug/IRENA_Geothermal_ Power_2017.pdf

33. (2013) A study prepared in partnership with the environmental protection agency for the RE-Powering America's Land Initiative: siting renewable energy on potentially contaminated land and mine sites. https:// www.nrel.gov/docs/fy14osti/60251.pdf

34. European Geothermal Energy Council. Geothermal electricity and combined heat \& power. European Geothermal Energy Council. https://www.
globalccsinstitute.com/archive/hub/publications/121288/Geothermalelectricity-combined-heat-power.pdf

35. Marugun RS, Subbarao PM (2008) Thermodynamic analysis of RankineKalina combined cycle. Int J Thermodyn. 11(3):133-141. https://dergipark. org.tr/en/pub/ijot/issue/5769/76761.

36. Shehata JM (2019) Power generation system with low enthalpy geothermal source: Kalina cycle. Int J Innov Sci Res Technol, 4(3):208-216, Art no IJISRT19MA352. https://ijisrt.com/wp-content/uploads/2019/04/IJISR T19MA352.pdf

37. Kahlen L, Kurdziel M, Day T, Schiefer T. The role of geothermal and coal in Kenya's electricity sector and implications for sustainable development. New Climate Institute. https://newclimate.org/wp-content/uploads/ 2019/11/The-role-of-geothermal-and-Kenya\%E2\%80\%99s-electricitysector-and-implications-for-sustainable

38. Kabeyi MJK (2020) Investigating the challenges of bagasse co-generation in the Kenyan sugar industry. Int J Eng Sci Res Technol 9(5):7-64. https:// doi.org/10.5281/zenodo.3828855

39. Hance CN, Gawell K (2005) Factors affecting cost of geothermal power development and production. GRC Trans 29:449-454

40. Aragón-Aguilar A, Izquierdo-Montalvo G, Aragón-Gaspa DO, BarretoRivera DN. Stages of an integrated geothermal project. https://doi.org/10. 5772/intechopen.81017

41. Kabeyi MJB (2019) Evolution of project management, monitoring and evaluation, with historical events and projects that have shaped the development of project management as a profession. Int J Sci Res 8(12):63-79. https://doi.org/10.21275/ART20202078

42. Kabeyi MJB (2019) Project and program evaluation consultancy with terms of reference, challenges, opportunities, and recommendations. Int J Sci Res Publ 9(12):171-194. https://doi.org/10.29322/IJSRP.9.12.2019. p9622

43. Adityatama D, Umam M, Purba D, Muhammad F (2019) Review on geothermal direct use application as an alternative approach in Community engagement at early exploration phase in Indonesia. Presented at the 44th workshop on geothermal reservoir engineering Stanford University, Stanford, California, February 11-13, 2019, SGP-TR-214. https://pangea. stanford.edu/ERE/pdf/IGAstandard/SGW/2019/Adityatama.pdf

44. Ngomi G, Mangi P (2017) Project management for geothermal energy development. Presented at the SDG Short Course II on exploration and development of geothermal Resources, Lake Bogoria and Lake Naivasha, Kenya, Nov. 9-29, 2017. https://orkustofnun.is/gogn/unu-gtp-sc/UNUGTP-SC-25-1006.pdf

45. Kenya Electricity Generating Company Plc. KenGen's wellhead technology. Kenya Electricity Generating Company Ltd. https://www.kengen.co. $\mathrm{ke} / \mathrm{q} \mathrm{q}=$ content/kengen-wellhead-technology. Accessed 2020

46. Kibet R, Bwoma R. KenGen's wellhead technology experience and business insight. Presented at the proceedings of World Geothermal Congress, Melbourne, Australia, 2015. https://www.geothermal-energy.org/ pdf/IGAstandard/ARGeo/2012/Kibet.pdf

47. Barasa PJ, Magut PKS (2018) Environmental risk assessment: case study of Eburru geothermal wellhead power plant. Int J Dev Sustain, 7(10): 2570-2584. https://isdsnet.com/ijds-v7n10-20.pdf

48. Barasa PJ, Mathenge RW (2015) Stakeholder engagement through participatory research: a case study of Eburru Geothermal Wellhead Generator in Nakuru County, Kenya. GRC Trans, 39:233-238. http://pubs. geothermal-library.org/lib/grc/1032155.pdf

49. Kabeyi MJB (2019) Organizational strategic planning, implementation and evaluation with analysis of challenges and benefits for profit and nonprofit organizations. Int J Appl Res 5(6):27-32. https://doi.org/10. 22271/allresearch.2019.v5.i6a.5870

50. Kombe EY, Muguthu J (2018) Geothermal energy development in East Africa: barriers and strategies. J Energy Res Rev, 2(1): 1-6, Art no JENRR.45278, https://doi.org/10.9734/JENRR/2019/45278

51. Ballzus C, Frimannson H, Gunnarsson Gl, Hrolfsson I (2000) The geothermal power plant at Nesjavellir, Iceland. In: Presented at the proceedings World Geothermal Congress 2000 Kyushu-Tohoku, Japan, May 28-June 10, 2000. https://www.geothermal-energy.org/pdf/IGAstandard/WGC/ 2000/R0596.PDF

52. MC Engineers. Nesjavellir combined heat and power plant. Mannvit Consulting Engineers. https://www.mannvit.com/projects/nesjavellir-combi ned-heat-and-power-plant/. Accessed 2020 
53. Chege PB, Richter GA (2017) KenGen's successful implementation of a modular geothermal wellhead strategy. GRC Trans, 41. http://pubs.geoth ermal-library.org/lib/grc/1033878.pdf

54. Saitel D, Kwambai C (2015) Wellhead generating plants: KenGen's experience. Presented at the proceedings World Geothermal Congress 2015, Melbourne, Australia, 19-25 April 2015. https://pangea.stanford.edu/ERE/ db/WGC/papers/WGC/2015/08016.pdf

55. Imaidi DL. Analysis of maintenance methods and developing strategies for optimal maintenance of wellhead power plants at Olkaria Geothermal field in Kenya. United Nations University, IS-108 Reykjavik, Iceland 12, 2017. https://orkustofnun.is/gogn/unu-gtp-report/UNU-GTP-2017-12.pdf

56. Gudmundsson YH, E (2016) Wellhead power plants. Presented at the proceedings of 6th African Rift Geothermal Congress, Addis Ababa, Ethiopia, 2-4th November 2016. http://theargeo.org/fullpapers/WELLHEAD\% 20POWER\%20PLANTS.pdf

57. Green Energy Geothermal. Green Energy Geothermal success story. Green Energy Geothermal. https://electricenergyonline.com/article/ energy/category/generation/52/719454/. Accessed 2020

58. Haraldsson IG (2016) Efficiency in geothermal utilization processes. Presented at the SDG Short Course I on sustainability and environmental management of geothermal resource Utilization and the role of geothermal in combating climate change Santa Tecla, El Salvador September 4-10, 2016. https://orkustofnun.is/gogn/unu-gtp-sc/UNU-GTP-SC-22-12. pdf

59. Ganguly S, Kumar MS (2012) Geothermal reservoirs - a brief review. J Geol Soc India 79:589-602. https://doi.org/10.1007/s12594-012-0098-8

60. Khasani, Abdullah FS (2018) Thermodynamics analysis of single-flash wellhead geothermal power plant at Jailolo field, Halmahera. Presented at the AIP conference proceedings, 16 August 2018. https://aip.scitation. org/doi/pdf/https://doi.org/10.1063/1.5049984?class=pdf

61. Bonalumi D, Borbarda PA, Inverrnizzi CM (2017) Zero emission geothermal flash power plant. Presented at the 72nd conference of the Italian Thermal Machines Engineering Association, Lecce, Italy, 6-8 September 2017, ATI2017. https://pdf.sciencedirectassets.com/277910/1-s2.0-S1876 610217X00222/1-s2.0-S1876610217338146/main.pdf

62. Elíasson ST, Thorhallsson S, Steingrímsson B. Geothermal power plants. In: United Nations University Geothermal Training Programme (UNUGTP). Santa Tecla, El Salvador, March 23-29, 2014 2014: United Nations University, in short course VI on utilization of low- and medium-enthalpy geothermal resources and financial aspects of utilization. http://hdl. handle.net/10802/5432

63. Wada K, Maedomari J, Furuya K (2017) Small geothermal power generation system for well head. GRC Trans, 41:1-5. http://pubs.geothermal-libra ry.org/lib/grc/1033778.pdf
64. Forsha M (1994) Low temperature flash steam plants, Geothermal Resource Council Transactions. GRC Trans 18:515-522

65. Frick S, Kranz S, Kupfermann G, Saadat A, Huenges E (2019) Making use of geothermal brine in Indonesia: binary demonstration power plant Lahendong/Pangolombian. Geotherm Energy, 7(30):1-19, Art no 30.https://doi. org/10.1186/s40517-019-0147-2

66. Kabeyi MJB (2020) Corporate governance in manufacturing and management with analysis of governance failures at Enron and Volkswagen Corporations. Am J Oper Manage Inform Syst 4(4):109-123. https://doi. org/10.11648/j.ajomis.20190404.11

67. Kabeyi MJB, Oludolapo AO (2020) Performance analysis of an open cycle gas turbine power plant in grid electricity generation. Presented at the 2020 IEEE international conference on industrial engineering and engineering management (IEEM), Singapore, Singapore, 14-17 December 2020, IEEM20-P-0438. https://ieeexplore.ieee.org/stamp/stamp.jsp?tp=\& arnumber $=9309840$

68. Kabeyi MJB, Oludolapo AO (2020) Performance analysis of diesel engine powerplants for grid electricity supply. In: 31st annual Southern African institute for Industrial Engineering conference, South Africa, 5th-7th October 2020, vol 2020, no 31: South African Institution of Industrial Engineers, pp 236-250. https://www.dropbox.com/s/o0sj1108v8n9sgh/ SAllE31\%20Conference\%20Proceedings.pdf?dl=

69. Balat M (2005) Usage of Energy Sources and Environmental Problems. Energy Explor Exploit 23(2):141-168. https://doi.org/10.1260/0144598054 530011

70. Mizuno E (2013) Geothermal power development in New Zealand -Lessons for Japan. Japan Renewable Energy Foundation, Tokyo, Japan. https://www.renewable-ei.org/en/images/pdf/20130220/20120912_ lessonfromNewZealand.pdf

71. Hance CN, Gladewell K (2005) Factors affecting cost of geothermal power development. GRC Trans, 29:450-452. http://pubs.geothermal-library. org/lib/grc/1022637.pdf.

72. Kabeyi MJB, Oludolapo AO (2020) Characteristics and application of geothermal wellhead powerplants in electricity generation. In: SAlIE31 proceedings, Virtual event, South Africa, 5th-7th October 2020, vol 31, South Africa: South African Institution of Industrial Engineer, pp 1-14

\section{Publisher's Note}

Springer Nature remains neutral with regard to jurisdictional claims in published maps and institutional affiliations.
Ready to submit your research? Choose BMC and benefit from:

- fast, convenient online submission

- thorough peer review by experienced researchers in your field

- rapid publication on acceptance

- support for research data, including large and complex data types

- gold Open Access which fosters wider collaboration and increased citations

- maximum visibility for your research: over $100 \mathrm{M}$ website views per year

At BMC, research is always in progress.

Learn more biomedcentral.com/submissions 